Article

\title{
Analyzing Renewable Energy Sources of a Developing Country for Sustainable Development: An Integrated Fuzzy Based-Decision Methodology
}

\author{
Yasir Ahmed Solangi ${ }^{1, *(\mathbb{D}}$, Cheng Longsheng ${ }^{1, *}$, Syed Ahsan Ali Shah ${ }^{1} \mathbb{D}$, Ahmed Alsanad ${ }^{2, *}$, \\ Munir Ahmad ${ }^{3}$ (D), Muhammad Azeem Akbar ${ }^{4}$, Abdu Gumaei ${ }^{2}$ and Sharafat Ali ${ }^{5,6,7}$ (D) \\ 1 School of Economics and Management, Nanjing University of Science and Technology, Nanjing 210094, \\ China; ahsan.shah1@hotmail.com \\ 2 STC's Artificial Intelligence Chair, Department of Information Systems, College of Computer and \\ Information Sciences, King Saud University, Riyadh 11451, Saudi Arabia; abdugumaei@gmail.com \\ 3 School of Economics, Zhejiang University, Hangzhou 310058, China; munirahmad@zju.edu.cn \\ 4 College of Computer Science and Technology, Nanjing University of Aeronautics and Astronautics, \\ Nanjing 210016, China; azeem.akbar@ymail.com \\ 5 College of Economics and Management, Nanjing University of Aeronautics and Astronautics, \\ Nanjing 210016, China; sharafat.ali@nuaa.edu.cn or sharafat.ali.rana@gmail.com \\ 6 Department of Economics, Bahauddin Zakaria University, Multan 60000, Pakistan \\ 7 Higher Education Department (HED), Punjab 54000, Pakistan \\ * Correspondence: yasir.solangi@nuaa.edu.cn (Y.A.S.); cheng_longsheng@njust.edu.cn (C.L.); \\ aasanad@ksu.edu.sa (A.A.)
}

Received: 7 June 2020; Accepted: 10 July 2020; Published: 13 July 2020

\begin{abstract}
Global human pollutant activities have raised greenhouse gas (GHG) emissions, which have directly affected the climate. Fossil fuel-based energy has brought a negative impact on the environment and is considered one of the largest sources of GHG emissions. It is envisaged that GHG emissions will increase in the future due to rapid population growth and industrialization. Thus, it is imperative to mitigate climate variability and reduce GHGs by adopting renewable energy (RE) sources for electricity generation. In this regard, the multi-criteria decision analysis (MCDA) process would serve the purpose of framing out energy policy to analyze these environmentally friendly energy sources. This study uses an integrated decision methodology-a combination of Delphi, fuzzy analytical hierarchy process (FAHP), and the fuzzy weighted aggregated sum product assessment (FWASPAS) - for the adoption of RE sources for electricity generation in Turkey. Initially, the study identified five main criteria and seventeen sub-criteria using the Delphi method. Then, the FAHP method was used to evaluate and rank the main criteria and sub-criteria. Finally, the FWASPAS method was used to assess and prioritize five major RE sources for electricity generation. The FAHP analysis indicated that political criteria are the most influential, followed by economic and technical criteria. Further, the FWASPAS method revealed that wind energy is the most significant option for electricity generation. This decision-making process can help the energy planners to utilize RE sources for sustainable development.
\end{abstract}

Keywords: renewable energy sources; sustainable development; multi-criteria decision analysis; Delphi; fuzzy AHP; fuzzy WASPAS

\section{Introduction}

Globally, the rampant increase in population, increased urbanization, and extended industrialization have been the main reasons for increasing energy consumption [1]. This increasing 
trend in energy demand has been causing environmental damage. Most of the countries in the world rely on fossil-fuel-based energy sources, which are the prime causes of global warming and climate change due to unprecedented increased levels of carbon emission. In the wake of the Paris agreement, mitigation and adaptation efforts are underway to reduce the reliance on traditional sources of energy. During the last decade, the global community has put forth strategies to implement sustainable energy policies to increase the utilization of renewable energy (RE) sources, such as solar, wind, hydro, and biomass for electricity generation [2]. Thus, the European Union (EU) has also adopted mitigation policies and strategies to protect environmental quality [3]. Adoption of low-carbon energy sources and a reduction in the usage of fossil fuels is fundamentally important for economic, environmental, social, technical, and political development [4]. However, it is quite difficult to determine the most feasible RE source to be utilized for electricity generation. Experts need to analyze the various RE technologies with respect to the multiple criteria and sub-criteria of the decision-making problem. This would provide important guidelines for the installation of RE technology, ensuring sustainable development.

Turkey is greatly dependent on imported energy sources, which account for $70 \%$ of its total energy consumption [5]. Fortunately, Turkey has a vast potential for RE sources, due to its geographical location. However, the share of RE is smaller in the total energy mix of the economy. Effective energy policies and strategies are required to promote RE projects. The RE technologies have numerous advantages due to their eco-friendly nature, and the use of such resources will help eliminate the imported energy supply, improve energy security and sustainable economic growth, and reduce GHG emissions. In addition to this, it would enable macroeconomic stability of the economy by decreasing the burden of energy imports and increase the share of domestic renewable resources. Moreover, the Turkish government has set a target to produce 30\% of its total energy supply from RE sources by 2023 [6]. An energy strategy plan has been introduced, which aims to increase the electricity production capacity to 20,000 MW from wind energy by 2023. The Turkish government is also promoting and encouraging stakeholders to invest in solar and wind energy projects. Thus, the government has provided various incentive schemes to stimulate investment for the use of RE sources [7].

The installation of RE projects requires comprehensive planning and implementation of the projects considering environmental, economic, technical, political, and social aspects. The multi-criteria decision analysis (MCDA) serves this purpose well and enables the energy planners and policymakers to make assessment and analysis of these renewable projects [8]. The fuzzy-based MCDA models enable the minimization of uncertainty in human decision-making and provide robust results [9]. The selection of the most suitable RE source is an MCDA problem, due to its various conflicting criteria, such as socio-economic, environmental, and political factors involved, in assessing multiple RE sources for electricity generation. Therefore, a comprehensive decision-making process is required in order to achieve the objective and solve the decision-making problem.

This research aims to propose a detailed set of criteria and sub-criteria to analyze and rank RE sources for electricity generation in Turkey. For this purpose, the Delphi method, fuzzy analytical hierarchy process (FAHP) and fuzzy weighted aggregated sum product assessment (FWASPAS) methods were used to evaluate RE sources under a fuzzy environment. This research successfully attempts to analyze the main criteria and sub-criteria of RE sources. This is the very first study that utilizes the Delphi, FAHP, and FWASPAS methodologies to evaluate RE sources. In this study, the Delphi method is used to identify and finalize the main criteria and sub-criteria based on experts' opinion and a literature review. Next, the FAHP approach is used to evaluate and prioritize main criteria and sub-criteria. Finally, the FWASPAS method is utilized to rank the RE sources for electricity generation in Turkey. This integrated decision methodology increases the robustness and effectiveness of the decision-making process.

\section{Related Studies}

In the decision-making process, it is complicated to determine the energy planning problem, since various uncertainties and fuzziness affect the decision. These uncertainties are not only 
socio-economic and technical, but also environmental and political [10]. Therefore, the MCDA approaches are suitable for analyzing the energy planning problem.

\subsection{Applications of MCDA Methods Used in Sustainable Energy Planning}

The MCDA techniques are considered crucial in analyzing the energy planning decision-making problem. Numerous studies have used different types of MCDA techniques with different aims and objectives. Table 1 shows the MCDA approaches employed for sustainable energy planning problems.

Table 1. The summary of various sustainable energy planning studies.

\begin{tabular}{|c|c|c|c|}
\hline Research Focus & Research Method & Region & Reference \\
\hline $\begin{array}{l}\text { Portfolio of RE sources for accomplishing } \\
\text { the 3-E policy goals }\end{array}$ & AHP & Taiwan & {$[11]$} \\
\hline $\begin{array}{l}\text { RE and nuclear sources selection for } \\
\text { electricity generation }\end{array}$ & AHP & Kazakhstan & [12] \\
\hline $\begin{array}{l}\text { Evaluating and selecting RE sources for } \\
\text { electricity generation }\end{array}$ & AHP & Algeria & [13] \\
\hline $\begin{array}{l}\text { RE sources selection for sustainable } \\
\text { electricity generation }\end{array}$ & AHP & Malaysia & [14] \\
\hline $\begin{array}{l}\text { Evaluating sustainable energy planning } \\
\text { and management }\end{array}$ & Fuzzy AHP & India & [15] \\
\hline $\begin{array}{l}\text { The selection of RE alternatives for } \\
\text { electricity production }\end{array}$ & Fuzzy AHP & Indonesia & [16] \\
\hline $\begin{array}{l}\text { Analyzing energy performance for } \\
\text { sustainable development }\end{array}$ & $\begin{array}{c}\text { AHP-Technique for Order of } \\
\text { Preference by Similarity to Ideal } \\
\text { Solution (TOPSIS) and } \\
\text { VlseKriterijumska Optimizcija I } \\
\text { Kaompromisno Resenje (VIKOR) }\end{array}$ & Turkey & [17] \\
\hline $\begin{array}{l}\text { Assessing the RE sources to accomplish } \\
\text { policy scenario goals }\end{array}$ & Fuzzy TOPSIS & Europe & [18] \\
\hline $\begin{array}{l}\text { Analyzing and ranking the most efficient } \\
\text { low-emission energy technologies }\end{array}$ & Fuzzy AHP-Fuzzy TOPSIS & Poland & [19] \\
\hline Selection of wind power project locations & AHP-Fuzzy TOPSIS & Pakistan & [20] \\
\hline Ranking the low-carbon energy sources & AHP and TOPSIS & China & [21] \\
\hline $\begin{array}{l}\text { Multi-criteria assessment of renewable } \\
\text { micro-generation technologies }\end{array}$ & $\begin{array}{l}\text { TOPSIS, Evaluation Based on } \\
\text { Distance from Average Solution } \\
\text { (EDAS) and WASPAS }\end{array}$ & Lithuania & [22] \\
\hline
\end{tabular}

It is determined from the literature that MCDA approaches greatly help in addressing and assessing sustainable energy planning problems. In this study, the fuzzy-based AHP and WASPAS methods have been applied because the fuzzy set theory is a valuable technique that helps in minimizing the uncertainty of the decision problem [23]. Therefore, this research contributes to the existing literature by proposing Delphi, FAHP, and FWASPAS methodologies for the selection and evaluation of RE sources in the context of Turkey.

\subsection{Identification of Main-Criteria and Sub-Criteria}

In the study, five main criteria and seventeen sub-criteria were identified from the literature. These criteria and sub-criteria are useful in evaluating RE sources for electricity generation in Turkey. Table 2 presents the RE main criteria and sub-criteria of the study. 
Table 2. RE main criteria and sub-criteria.

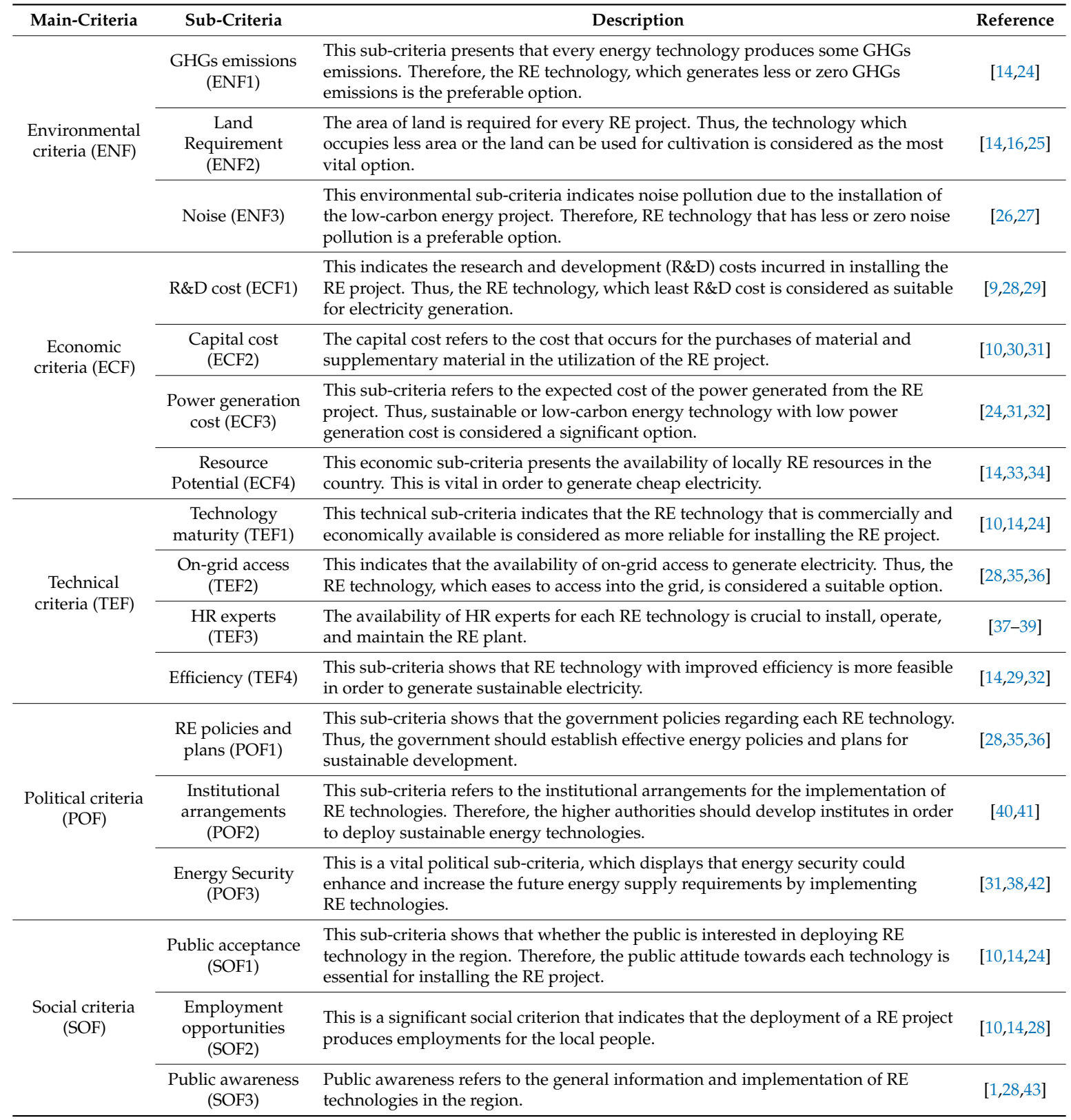

It was identified that MCDA techniques are very useful in solving the energy planning decision-making problem. To the best of our understanding, this is the very first effort to analyze and select the RE sources based on Delphi, FAHP, and FWASPAS methodologies. Therefore, in the present study, Delphi, FAHP, and the FWASPAS methods are used to assess and rank RE sources in Turkey.

\section{Overview of Renewable Energy Sources in Turkey}

$\mathrm{RE}$ is defined as energy sources that are continually replenished by nature with lower GHG emissions [44]. Turkey has significant RE potential to produce electricity generation. The major RE sources for Turkey are solar, wind, hydro, geothermal, and bioenergy [45]. Table 3 presents the potential of these RE sources. 
Table 3. Turkey's RE sources installed capacity, future target, and resource availability [46].

\begin{tabular}{cccc}
\hline RE Source & By the End of 2018 (MW) & 2023 Target (MW) & Resource Availability (MW) \\
\hline Solar PV & 5062 & 10,000 & 50,000 \\
Wind & 6925 & 20,000 & 48,000 \\
Hydropower & 27,912 & 34,000 & 36,000 \\
Geothermal & 1261 & 1000 & 2000 \\
Bioenergy & 526 & 1500 & 2000 \\
\hline
\end{tabular}

\subsection{Solar Energy}

Turkey has a vast potential for solar energy as the location of the country lies in a region of high solar radiation, i.e., between $36^{\circ} \mathrm{N}$ and $42^{\circ} \mathrm{N}$ latitudes [47]. The country receives a total annual solar radiation duration of $2741 \mathrm{~h}$ (a total of $7.5 \mathrm{~h} /$ day), and the total solar energy derived per year is $1527 \mathrm{kWh} / \mathrm{m}^{2}$ per year (total $4.18 \mathrm{kWh} / \mathrm{m}^{2} /$ day) [48]. The black sea region and southeast Anatolia have sufficient solar energy to generate electricity. Solar energy would be a guarantee to mitigate dependency on energy imports and enhance energy security for the sustainable development of Turkey. The direct normal irradiation map of Turkey is presented in Figure 1 [49].

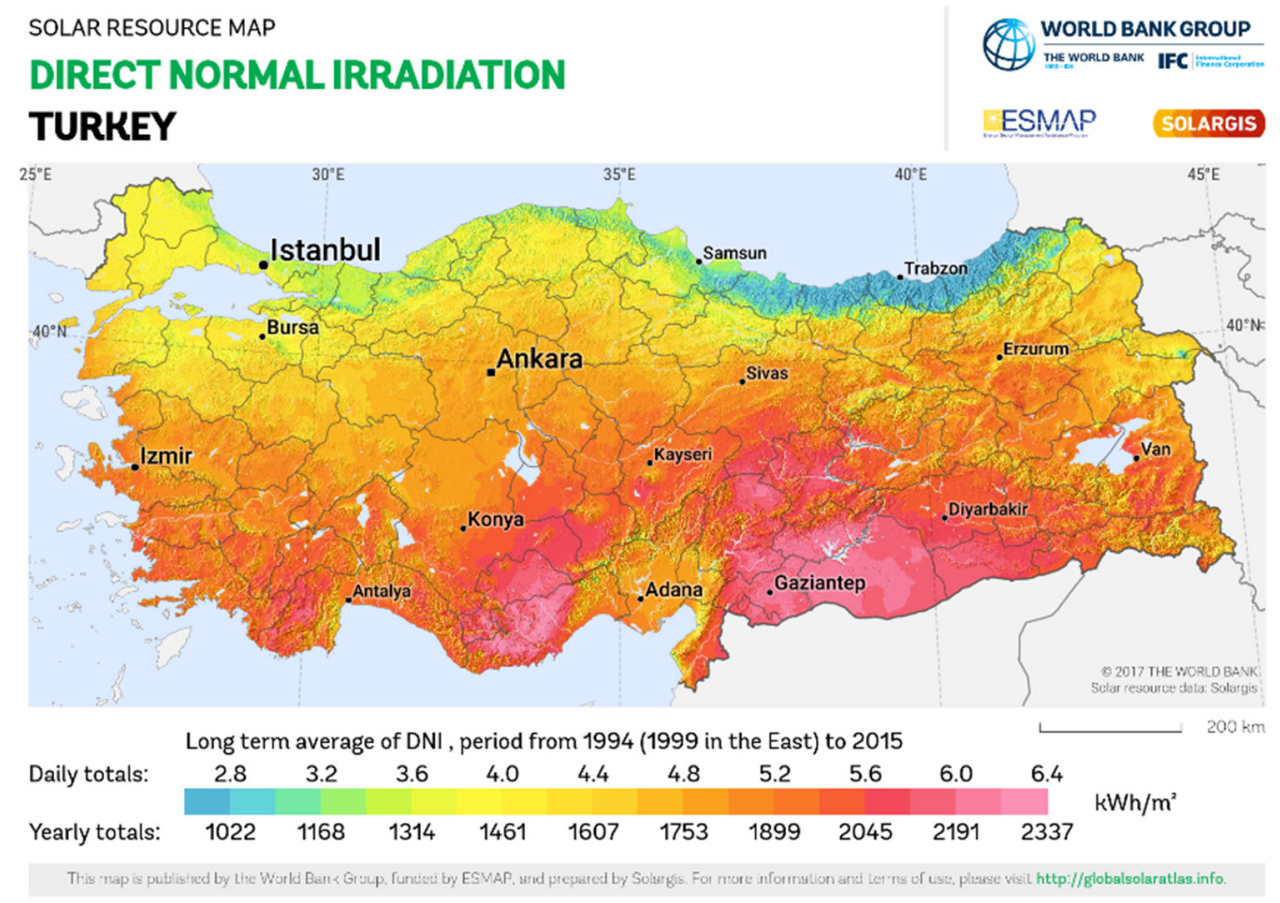

Figure 1. Solar energy map of Turkey.

\subsection{Wind Energy}

Wind energy is a substantial low-carbon energy source for producing sustainable electricity. Many countries in the world are benefiting from this renewable source by generating electricity. Turkey also has a large potential for wind energy in a number of cities and regions [50]. Wind speed, with a low of about $3.5 \mathrm{~m} / \mathrm{s}$ and a high of $5 \mathrm{~m} / \mathrm{s}$ at an anemometer height of $10 \mathrm{~m}$, is recorded in different regions of the country. The most attractive and potential windy regions in Turkey include the Marmara Sea region, the Aegean Sea Coast, the Mediterranean Coast, and Anatolia Island [51]. The country is hopefully installing new wind energy plants to produce electricity up to $20 \mathrm{GW}$ by 2023 [52]. This effort will help the country to supply $30 \%$ of electricity production from wind energy. In order to achieve this target, the government should initiate effective energy policies for stakeholders to minimize the risks in installing the RE project. 


\subsection{Hydropower}

Hydropower is a vital sustainable energy source for producing electricity in Turkey [6]. In the country, the total potential of hydropower is nearly $36 \mathrm{GW}$, or 190 billion $\mathrm{kWh} /$ year. However, this may drop to 130 billion $\mathrm{kWh} / \mathrm{year}$, due to climate change [53]. Turkey has planned to install more hydropower plants and expand to $45,000 \mathrm{MW}$ by 2020 for generating electricity. This energy plan would cost more than 40 billion US dollars. Further, hydropower is evaluated as a green and clean energy source. However, sometimes, due to negligence, while selecting the location of the dam, it can become hazardous to the environment as it causes the destruction or migration of its various inhabitants. Therefore, the government should offer an attractive and effective policy plan for stakeholders to invest in RE sources without facing any risk in project development.

\subsection{Geothermal Energy}

Turkey has substantial potential in geothermal energy. The available geothermal energy potential is approximately $2000 \mathrm{MW}$ to generate electricity [50]. The country's total geothermal heating capacity is around 31,500 MW, and heating capacity runs at $983 \mathrm{MW}$, which is equivalent to providing electricity to 120,000 households. The main cities that have geothermal district heating systems are Simav, Kırşehir, and Gönen [54]. Moreover, geothermal energy is considered environmentally-friendly technology, which produces only 75-80 $\mathrm{g} \mathrm{CO}_{2}$-eq/kWh [55]; however, other energy sources generate more GHGs.

\subsection{Bioenergy}

Turkey is an agricultural country with significant potential for biomass production [56]. The various biomass sources, such as cotton stalks, wheat straw, sugar cane, corn cubs, animal dung, rice husk, and bagasse, are used inefficiently for cooking and heating purposes. If these sources can be appropriately managed, then they could be the source of biogas and rural electrification for cooking facilities. The total biomass potential is $168.7 \mathrm{TWh} /$ year in the country available for electricity generation [56]. Therefore, the Turkish government should also develop an evaluation program for biomass energy production in the country.

It is identified that the country is very rich in RE sources; therefore, it is essential to build sustainable energy plans and strategies for its development. However, analyzing these sustainable energy sources is a challenging and complex task with different opinions of stakeholders, governments, and policymakers. Therefore, this study develops an integrated decision methodology based on the Delphi, FAHP, and FWASPAS approaches for the selection of RE sources in Turkey.

\section{An Integrated Decision Methodology}

This research used Delphi, FAHP, and FWASPAS methodologies to analyze main criteria, sub-criteria, and RE sources for electricity generation in Turkey. Figure 2 shows the proposed integrated decision methodology of the current study. Firstly, the Delphi method was analyzed to finalize main criteria and sub-criteria. Secondly, the FAHP method was used to assess these criteria. Lastly, the FWASPAS approach was employed to rank the RE sources for sustainable electricity generation in Turkey. In this study, twelve experts took part during the Delphi, FAHP, and FWASPAS process. The consulted experts were asked to evaluate criteria, sub-criteria, and RE sources for sustainable development in Turkey. 


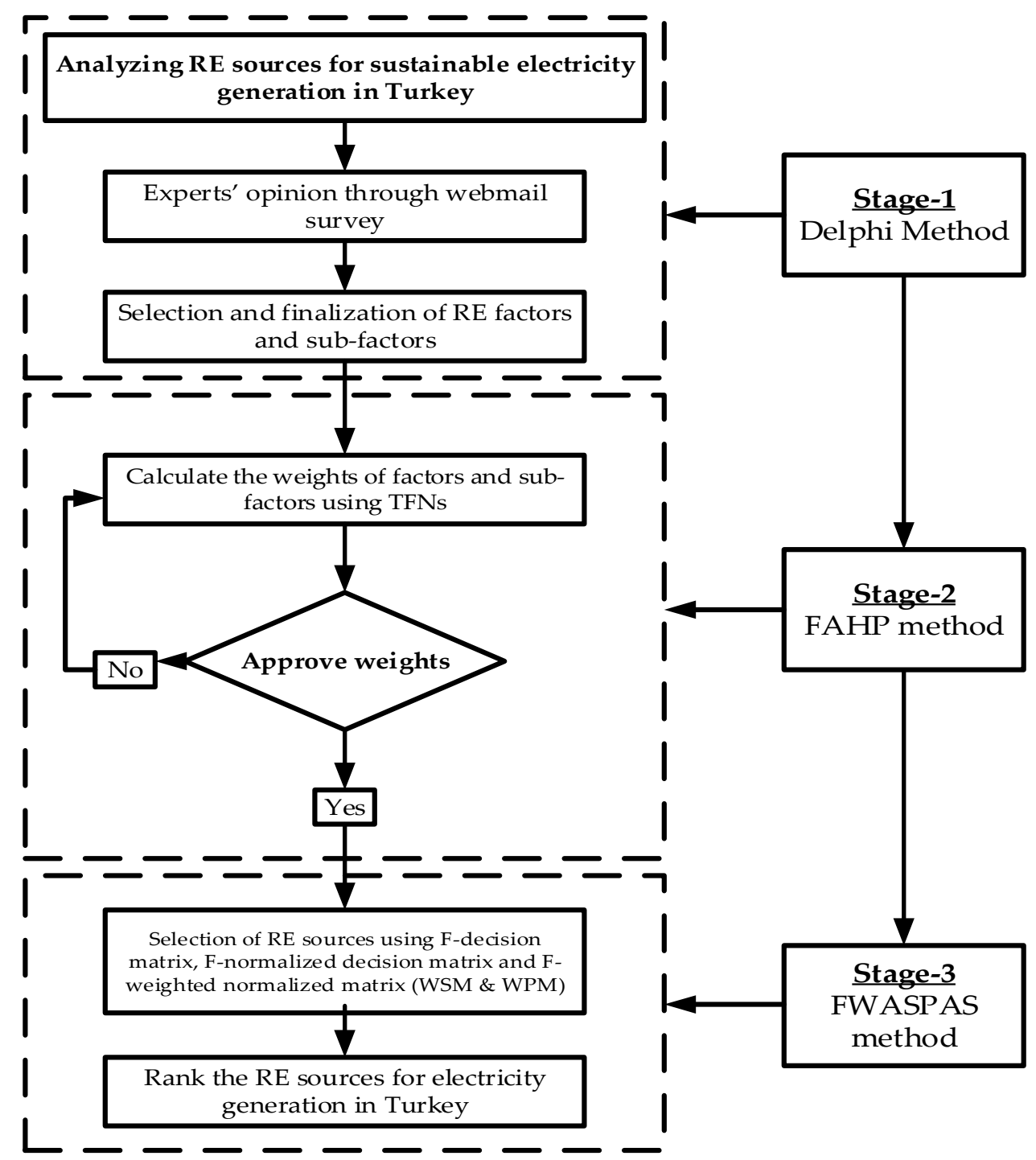

Figure 2. An integrated decision methodology.

\subsection{The Delphi Method}

In the present study, the Delphi method was utilized to analyze the important criteria and sub-criteria for sustainable energy deployment in Turkey. The purpose of using the Delphi method is to confirm the criteria by collecting and surveying experts' opinions about the particular problem. The survey can be obtained through group discussions, webmail services, semi-structured interviews, and questionnaires [57]. In this approach, the group of professional and experienced experts shares their feedback, knowledge, and ideas to form a mutual consensus on the decision problem [44]. Several vital steps are involved in the implementation of the Delphi method. These steps include the selection of decision-makers or experts and the first and second round of the questionnaire survey, and this process continues or repeats until the survey respondents reach a mutual consensus [58].

In the Delphi method, the researchers are not restricted on the number of survey respondents for determining the opinion for any particular problem. However, in the literature, different studies have proposed different numbers of experts for validating the data, but 9 to 18 experts are feasible for analyzing the decision problem with respect to the Delphi process [59]. The presented study consulted with 12 experts to participate and provide meaningful opinions through a webmail service for analyzing the criteria and sub-criteria. Each of the experts was asked to provide weights using a five-point Likert scale. The questionnaire survey and expert details are provided in Appendix A. 


\subsection{FAHP Method}

AHP is a very important methodology of MCDA [60]. In this study, the fuzzy-based AHP was used to obtain more robust and reliable results in the fuzzy environment. The pairwise comparison was operated into a matrix using triangular fuzzy numbers (TFNs). The TFNs rating scale is shown in Table 4.

Table 4. TFNs Vcale [61].

\begin{tabular}{ccc}
\hline Number & Linguistic Variable & TFNs \\
\hline 1 & Equally important & $(1,1,1)$ \\
2 & Equally to average important & $(1,2,3)$ \\
3 & Averagely important & $(2,3,4)$ \\
4 & Averagely to strongly important & $(3,4,5)$ \\
5 & Strongly important & $(4,5,6)$ \\
6 & Strongly to very strongly important & $(5,6,7)$ \\
7 & Very strongly important & $(6,7,8)$ \\
8 & Very strongly to tremendously important & $(7,8,9)$ \\
9 & Tremendously important & $(9,9,9)$ \\
\hline
\end{tabular}

The procedure of the FAHP method was followed according to Ref. [62].

The matrices are considered consistent if the value of CR is less than 0.1. However, if the value of CR surpasses 0.1, then the results are considered inconsistent. Gogus and Boucher redeveloped the random index for fuzzy pairwise comparison matrices. Table 5 illustrates the RI value for each matrix, which was proposed by Gogus and Boucher.

Table 5. RI for each matrix.

\begin{tabular}{ccc}
\hline $\mathbf{N}$ & $\boldsymbol{R} \boldsymbol{I}_{\boldsymbol{m}}$ & $\boldsymbol{R} \boldsymbol{I}_{\boldsymbol{g}}$ \\
\hline 1 & 0 & 1 \\
2 & 0 & 2 \\
3 & 0.48 & 0.17 \\
4 & 0.79 & 0.26 \\
5 & 1.07 & 0.35 \\
6 & 1.19 & 0.38 \\
7 & 1.28 & 0.40 \\
8 & 1.34 & 0.41 \\
9 & 1.37 & 0.43 \\
10 & 1.40 & 0.44 \\
\hline
\end{tabular}

\subsection{FWASPAS Method}

The WASPAS method was proposed by Zavadskas in 2012 [63]. In this study, the WASPAS method extends with fuzzy set theory because this approach is very strong and provides a robust outcome in the fuzzy environment by assigning the relative importance of attributes using fuzzy numbers instead of precise numbers. The linguistic variables matching triangular fuzzy numbers (TFNs) are presented in Table 6.

Table 6. Linguistic variables for the importance weight of each attribute.

\begin{tabular}{ccc}
\hline Number & Linguistic Scale & TFNs \\
\hline 1 & Equal & $(1,1,1)$ \\
1 & Low & $(1,1,3)$ \\
3 & Moderate & $(1,3,5)$ \\
5 & High & $(3,5,7)$ \\
7 & Very high & $(5,7,9)$ \\
9 & Extreme & $(7,9,9)$ \\
\hline
\end{tabular}


The WASPAS method consists of two main aggregated parts [64]: (i) the weighted sum model (WSM); and (ii) the weighted product model (WPM). WSM determines the overall weight score of alternatives as a weighted sum of the attribute values, while the WPM method is proposed or developed in order to evade alternatives with deprived or poor attribute values. The mathematical steps of the FWASPAS method is provided in Ref. [65].

In this study, an integrated decision procedure was followed for the Delphi, FAHP, and FWASPAS methods. In the following sections, the evaluation process of the main criteria, sub-criteria, and RE sources was undertaken to analyze this decision-making problem.

\section{Results and Discussion}

This study proposed Delphi, FAHP, and FWASPAS approaches to analyze and rank RE sources to generate electricity in Turkey. First, the Delphi method finalized five main criteria and seventeen sub-criteria for the selection of RE sources. Next, FAHP was used to evaluate the various important criteria and sub-criteria. Finally, the FWASPAS method was employed to rank RE sources for electricity generation.

\subsection{Results of FAHP Method}

The FAHP technique was used to assess and prioritize the main criteria and sub-criteria, while the FWASPAS method was employed to rank the RE sources to accomplish the goal of the study. Therefore, the four-level hierarchical decision framework is presented in Figure 3. The detailed analysis, i.e., the fuzzy pairwise comparison of the main criteria and sub-criteria using the FAHP method, is shown in Appendix B. In the following sections, the results of FAHP are presented.

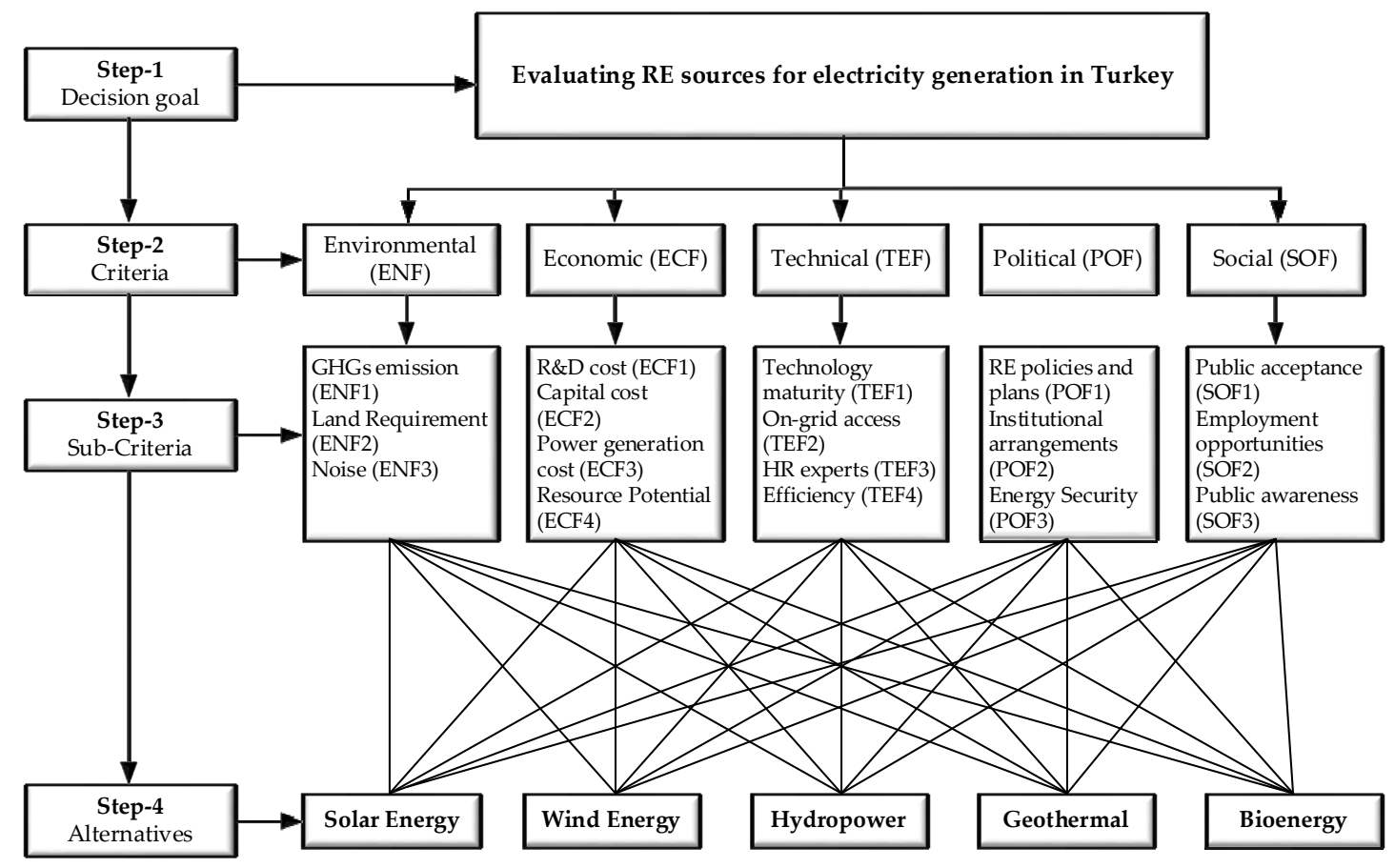

Figure 3. Hierarchical decision framework.

\subsubsection{Ranking of Main-Criteria and Sub-Criteria}

In this section, the main criteria and sub-criteria of RE sources were identified using the FAHP technique. Table 7 shows the ranking of the main criteria and sub-criteria, with respect to the decision goal of the study. The results show that the political criterion (POF), with a weight of $0.266(26.60 \%)$, is an essential criterion for the selection of RE sources. The economic criterion (ECF) is considered the second most important criterion, with a weight of 0.234 (23.40\%). Moreover, the technical (TEF) and 
environmental (ENF) criteria obtained the third and fourth rank, respectively, for the evaluation of RE sources. The social criterion (SOF), with a weight of 0.139 (13.90\%), received the lowest weight score. Thus, the ranking of each criterion shows its importance in analyzing RE sources for electricity generation in Turkey.

Table 7. Ranking of main criteria and sub-criteria.

\begin{tabular}{|c|c|c|c|c|c|}
\hline Criteria & $\begin{array}{l}\text { Main-Criteria } \\
\text { Weight }\end{array}$ & $\begin{array}{l}\text { Main-Criteria } \\
\text { Rank }\end{array}$ & Sub-Criteria & $\begin{array}{l}\text { Sub-Criteria } \\
\text { Weight }\end{array}$ & $\begin{array}{l}\text { Sub-Criteria } \\
\text { Rank }\end{array}$ \\
\hline \multirow{3}{*}{$\begin{array}{l}\text { Environmental } \\
\text { (ENF) }\end{array}$} & \multirow{3}{*}{0.155} & \multirow{3}{*}{4} & GHGs emission (ENF1) & 0.332 & 2 \\
\hline & & & Land requirements (ENF2) & 0.349 & 1 \\
\hline & & & Noise (ENF3) & 0.319 & 3 \\
\hline \multirow{4}{*}{ Economic (ECF) } & \multirow{4}{*}{0.234} & \multirow{4}{*}{2} & $R \& D$ cost $(E C F 1)$ & 0.247 & 3 \\
\hline & & & Capital cost (ECF2) & 0.268 & 1 \\
\hline & & & Power generation cost (ECF3) & 0.250 & 2 \\
\hline & & & Resource Potential (ECF4) & 0.235 & 4 \\
\hline \multirow{4}{*}{ Technical (TEF) } & \multirow{4}{*}{0.206} & \multirow{4}{*}{3} & Technology maturity (TEF1) & 0.268 & 1 \\
\hline & & & On-grid access (TEF2) & 0.233 & 4 \\
\hline & & & HR experts (TEF3) & 0.248 & 3 \\
\hline & & & Efficiency (TEF4) & 0.251 & 2 \\
\hline \multirow{3}{*}{ Political (POF) } & \multirow{3}{*}{0.266} & \multirow{3}{*}{1} & RE policies and plans (POF1) & 0.394 & 1 \\
\hline & & & Institutional arrangements (POF2) & 0.362 & 2 \\
\hline & & & Energy Security (POF3) & 0.244 & 3 \\
\hline \multirow{3}{*}{ Social (SOF) } & \multirow{3}{*}{0.139} & \multirow{3}{*}{5} & Public acceptance (SOF1) & 0.348 & 1 \\
\hline & & & Employment opportunities (SOF2) & 0.343 & 2 \\
\hline & & & Public awareness (SOF3) & 0.309 & 3 \\
\hline
\end{tabular}

It is identified from Table 7 that land requirements (ENF2) is the first-ranked sub-criterion, with a weight of 0.349 (34.90\%), from the environmental criterion (ENF) perspective, since obtaining the land for installing any RE project is the most important factor for the energy planners. The GHG emissions (ENF1) sub-criterion was second-ranked, with a weight of $0.332(33.20 \%)$. The RE technology, which produces less or zero carbon emissions, is considered a feasible option for sustainable electricity generation. Moreover, the noise (ENF3) sub-criterion achieved the least important weight of 0.319 $(31.90 \%)$. However, all the environmental sub-criteria are very crucial for producing sustainable electricity generation in Turkey.

It can be seen from Table 7 that capital cost (ECF2) is the most crucial sub-criterion, with a weight of $0.268(26.80 \%)$, for the deployment of RE projects in Turkey. This ECF2 sub-criterion belongs to economic criterion (ECF). The capital cost is important for installing any sustainable energy project, due to financial limitations and the unavailability of bank loans for investors. The power generation cost (ECF3) is considered the second-ranked sub-criterion, with a weight of 0.250 (25\%). The power generation cost of any sustainable energy project should be less than or convenient, as compared to fossil fuel electricity generation. The R\&D cost (ECF1) and resource potential (ECF4) were ranked as the third and fourth economic sub-criteria, respectively.

Moreover, it is identified that technology maturity (TEF1) is the first-priority sub-criterion, with a weight of $0.268(26.80 \%)$, from the technical criteria (TEF) perspective. This priority order indicates that technology is the crucial element for the expansion of any RE project. The efficiency (TEF4) and HR experts (TEF3) are the second- and third-ranked vital sub-criteria, respectively. Further, the on-grid access (TEF2) is the least important for the development of the sustainable energy project.

Further, it is identified that RE policies and plans (POF1) is the most feasible sub-criterion, with a weight of 0.3940 (39.40\%), from the political criterion (POF) perspective. This analysis shows that 
effective and efficient low-carbon energy policies are required to deploy the RE projects in order to generate sustainable electricity. The institutional arrangements (POF2) is the second-highest vital sub-criterion, with a weight of $0.3620(36.20 \%)$, whereas energy security (POF3) secured the third-ranked sub-criterion. Thus, it is essential that all these political sub-criteria are taken into account to produce sustainable electricity in Turkey.

From the social criterion (SOF) perspective, it is shown that public acceptance (SOF1) is the most important sub-criterion, with a weight of $0.348(34.80 \%)$. This indicates that public acceptance is a vital sub-criterion for implementing any RE project. The employment opportunities (SOF2) received the second-highest weight of $0.343(34.30 \%)$, while public awareness is the least essential sub-criterion with a weight of $0.309(30.90 \%)$. The analysis shows that all of these social sub-criteria are essential for installing the RE project.

\subsubsection{Ranking of Overall Sub-Criteria}

The overall sub-criteria results were identified using the FAHP method. The weights of the sub-criteria were multiplied with the main criteria weight to obtain the final weights. Table 8 shows the final weight of RE sub-criteria. Overall, seventeen sub-criteria were analyzed in the study. The results show that RE energy policies and plans (POF1) is the top-ranked sub-criterion, with a weight of $0.1048(10.48 \%)$, for sustainable electricity generation in Turkey. The institutional arrangements (POF2) appeared as the second important sub-criterion, while energy security (POF3) was considered as the third vital sub-criterion. These three sub-criteria belong to the political criterion (POF). The remaining prioritizing order of sustainable energy sub-criteria are as follows: ECF2 $<$ ECF3 $<$ ECF1 $<$ TEF1 $<$ ECF4 $<$ ENF2 < TEF4 < ENF1 < TEF3 < ENF3 < SOF1 < TEF2 < SOF2 < SOF3.

Table 8. Ranking of overall sub-criteria.

\begin{tabular}{llcc}
\hline Code & \multicolumn{1}{c}{ Sub-Criteria } & Final Weight & Rank \\
\hline ENF1 & GHGs emissions & 0.0514 & 11 \\
ENF2 & Land Requirement & 0.0540 & 9 \\
ENF3 & Noise & 0.0494 & 13 \\
ECF1 & R\&D cost & 0.0577 & 6 \\
ECF2 & Capital cost & 0.0627 & 4 \\
ECF3 & Power generation cost & 0.0585 & 5 \\
ECF4 & Resource Potential & 0.0549 & 8 \\
TEF1 & Technology maturity & 0.0552 & 7 \\
TEF2 & On-grid access & 0.0479 & 15 \\
TEF3 & HR experts & 0.0510 & 12 \\
TEF4 & Efficiency & 0.0517 & 10 \\
POF1 & RE policies and plans & 0.1048 & 1 \\
POF2 & Institutional arrangements & 0.0962 & 2 \\
POF3 & Energy Security & 0.0649 & 3 \\
SOF1 & Public acceptance & 0.0483 & 14 \\
SOF2 & Employment opportunities & 0.0476 & 16 \\
SOF3 & Public awareness & 0.0429 & 17 \\
\hline
\end{tabular}

\subsection{Results of FWASPAS Method}

Following the identification and analysis of the RE criteria and sub-criteria using the FAHP method, this section further evaluates five RE energy sources using the FWASPAS method. The experts' opinions helped in identifying the optimal RE sources for electricity generation in Turkey. The analysis was done using TFNs for constructing a fuzzy integrated decision matrix, fuzzy normalized decision matrix, and fuzzy weighted normalized decision matrix for WSM and WPM (see Appendix C).

The ranking order of five RE sources based on $X_{i}, Y_{i}$, and $K_{i}$ values is presented in Table 9. Further, the RE source with the highest value of $K_{i}$ is considered as the most feasible alternative; therefore, the final ranking of the RE sources is shown in Figure 4. The results of the FWASPAS indicate that wind 
energy, with a weight of 0.684 , is the most feasible option for generating electricity in Turkey, while solar energy is considered the second most important RE source, with a weight of 0.627. Hydropower obtained the third rank, with a weight of 0.617. Geothermal and bioenergy were considered the least important RE sources. Indeed, all these RE energy sources are very significant for sustainable electricity generation in Turkey.

Table 9. $X_{i}, Y_{i}$, and $K_{i}$ values of RE sources.

\begin{tabular}{cccccc}
\hline Code & RE Source & $\boldsymbol{X}_{\boldsymbol{i}}$ & $\boldsymbol{Y}_{\boldsymbol{i}}$ & $\boldsymbol{K}_{\boldsymbol{i}}$ & Rank \\
\hline A1 & Solar energy & 0.628 & 0.626 & 0.627 & 2 \\
A2 & Wind energy & 0.687 & 0.681 & 0.684 & 1 \\
A3 & Hydropower & 0.619 & 0.615 & 0.617 & 3 \\
A4 & Geothermal energy & 0.621 & 0.611 & 0.616 & 4 \\
A5 & Bioenergy & 0.599 & 0.589 & 0.594 & 5 \\
\hline
\end{tabular}

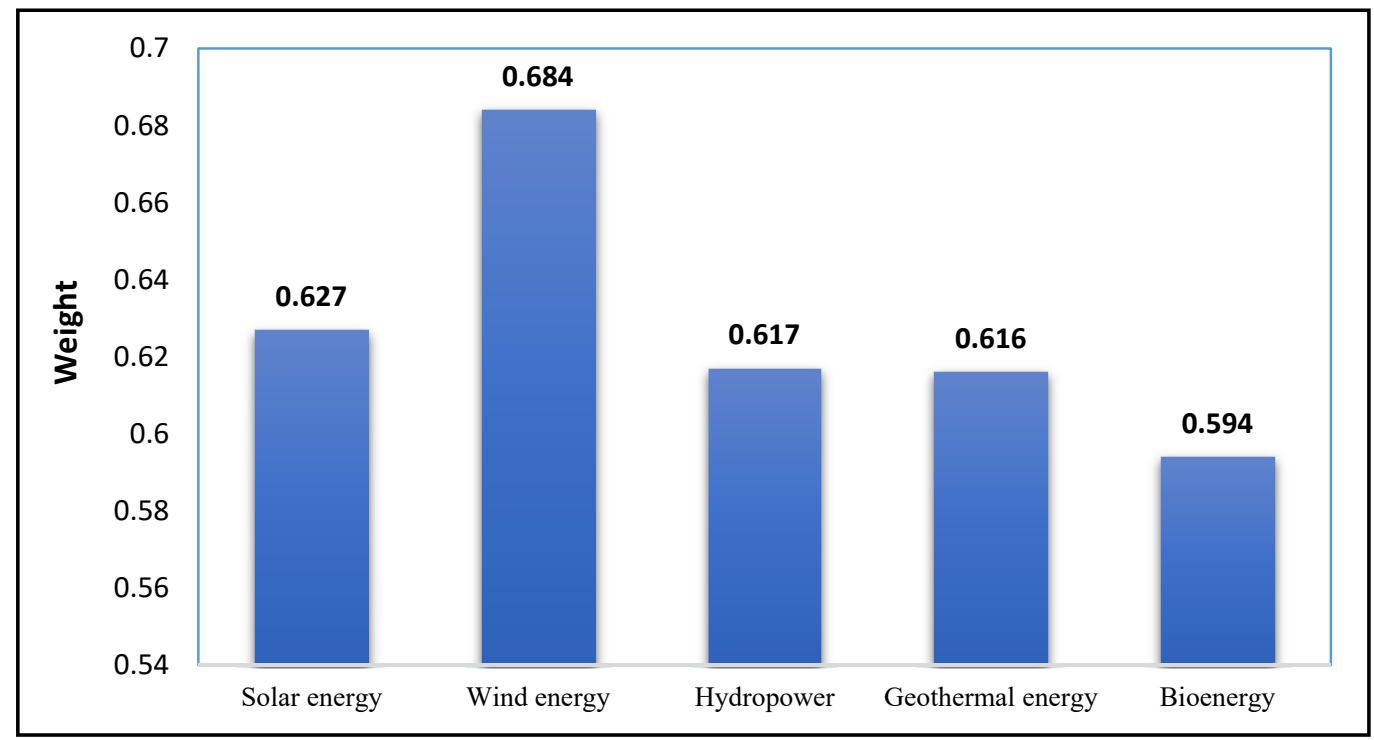

Figure 4. The final ranking of RE sources based on the highest value of $K_{i}$.

The objective of the current research was to assess the RE main criteria and sub-criteria and RE sources for sustainable electricity generation in Turkey. Thus, the FAHP and FWASPAS techniques were effectively used to address and analyze this energy planning problem.

\subsection{Discussion}

In this research, five RE resources were selected as a case study for Turkey. Each of the RE sources was analyzed with the proposed five main criteria and seventeen sub-criteria for adopting sustainable energy projects. The developed integrated decision methodology, i.e., the Delphi, FAHP, and FWASPAS techniques, were used to solve this multi-faceted problem. The FAHP results revealed that the political criterion (POF) is the most appropriate criterion for selecting a feasible RE source. The economic (ECF) and technical (TEC) criteria are moderately important criteria. Further, the results show that RE policies and plans (POF1) is the most crucial sub-criterion in assessing and selecting any RE source. The final results of the FWASPAS method show that wind energy is the most suitable sustainable technology for the development of energy projects.

This research identifies, evaluates, and prioritizes the main criteria and sub-criteria for implementing the RE project. After analyzing these criteria, the RE sources were ranked to produce sustainable electricity in Turkey. Several studies relating to the development of RE sources using different MCDA methods are available in the literature. Shen et al. [11] proposed RE sources portfolio 
in order to achieve economic, environmental, and energy policy goals for Taiwan using the AHP method. The authors indicate that solar energy, wind energy, and non-pumped storage hydropower can accomplish the economic, environmental, and energy policy goals of Taiwan. The findings of [12] show that the economic criterion is the most important criterion, and hydropower is the most significant sustainable energy source for electricity generation in Kazakhstan; in the study, the authors used the AHP method to analyze the decision-making problem. The study by [13] found that social and environmental criteria are the most crucial criteria, and solar energy is a suitable RE source in the context of Algeria. The results of the present study are partially similar to [14]; they found, using the AHP method, that the economic criterion is the main-criterion, and solar energy is the main RE source for sustainable electricity production in Malaysia. The analysis of the previous study using the FAHP method reveals that the environmental criterion is the most feasible dimension for sustainable evaluation in energy planning in India [15]. The authors analyzed the decision problem pertaining to the selection of RE alternatives using the FAHP method [16]. The results show that hydropower is a suitable RE alternative for electricity production. Moreover, [19] identified the most appropriate low-emission energy technology development in Poland using FAHP and FTOPSIS methodology; their results indicate that solar PV is the most feasible low-emission energy technology for electricity generation. Ren and Sovacool [21] analyzed and ranked the low-carbon energy sources of China using the AHP and TOPSIS methods. The authors selected four dimensions, ten matrices, and five low-carbon energy sources; their results indicate that availability is the most significant dimension, while hydropower and wind are the two important low-carbon energy sources to enhance the energy security of China. Zhang et al. [22] ranked the renewable micro-generation technologies in Lithuania based on TOPSIS, EDAS, and WASPAS methods; their results show that biomass boiler is the most significant micro-generation technology in households

There are several other studies in which authors used different MCDA methods to analyze a similar type of decision-making problem. However, in this research, we used Delphi, FAHP, and FWASPAS methods in order to assess the RE sources of Turkey. The proposed integrated decision methodology is validated using the Delphi, FAHP, and FWASPAS approaches. The aim was to select the feasible RE sources for electricity production in Turkey. The evaluation process of this study enables the government to implement RE source projects to produce electricity. Therefore, this study would be very useful for governments, stakeholders, and decision-makers to implement sustainable energy projects in the country.

\section{Conclusions}

Due to energy imports in Turkey, its consumers pay high prices for electricity. Nevertheless, the increasing population and industrialization have forced the government to deploy sustainable energy sources to complete the energy requirements of the country. Therefore, the country should utilize its RE sources, considering future energy needs. In this study, Delphi, FAHP, and FWASPAS methods were used to evaluate the RE sources of Turkey. First, the Delphi method finalized the important criteria and sub-criteria. Then, the FAHP was used to evaluate these identified criteria and sub-criteria. Finally, the FWASPAS approach was used to evaluate and rank the RE sources for electricity generation.

The results of the FAHP method revealed that the political criterion (POF) is the most significant criterion for the selection of RE sources. The economic (ENC) and technical (TEF) criteria were considered the second and third most important criteria, respectively. Further analysis indicated that RE policies and plans (POF1), institutional arrangements (POF2), and energy security (POF3) are the most significant sub-criteria for the selection of sustainable energy technology. Moreover, the results of the FWASPAS method showed that wind is the top-priority ranked RE source for producing electricity in Turkey. Solar energy and hydropower ranked second and third, respectively. Thus, wind energy has huge potential to generate electricity and could be sufficient to fulfill the current and future energy demands of the country. Furthermore, the implementation of wind energy sources can 
minimize environmental damage and reduce the dependence on traditional energy sources. Therefore, wind energy can play an essential role in the sustainable development of the country. Moreover, this source of energy is very useful for providing electricity to both urban and rural regions.

This study has several limitations that can be overcome in future research studies: for instance, the inclusion of more professional experts from various Turkish industries; it was not easy to approach them to participate in the survey. Sustainable energy is considered as a basic driving force for the economic development of any country. Nevertheless, due to various factors, the implementation of an RE project takes time and incurs delays, which also cause huge losses to the stakeholders. In this regard, proper sustainable energy policy should be planned by the government for the effective adoption of the RE project and sustainable development of the country. In the future, a similar type of study can be undertaken based on different MCDA methods, such as ANP, TOPSIS, DEA, VIKOR, and DEMATEL, for comparative purposes. Moreover, the researchers should identify more RE criteria and sub-criteria for the successful implementation of sustainable energy projects.

Author Contributions: Data curation, Y.A.S. and M.A.A.; Formal analysis, Y.A.S.; Investigation, S.A.A.S.; Methodology, Y.A.S. and S.A.A.S.; Project administration, M.A.; Software, A.A. and M.A.; Supervision, C.L.; Validation, C.L., S.A.A.S. and S.A.; Writing - original draft, Y.A.S.; Writing - review \& editing, C.L., M.A.A., A.G. and S.A. All authors have read and agreed to the published version of the manuscript.

Acknowledgments: The authors are grateful to the Deanship of Scientific Research, King Saud University, for funding through the Vice Deanship of Scientific Research Chairs.

Conflicts of Interest: The authors declare no conflict of interest.

\section{Appendix A. Questionnaire Survey on "Analyzing RE Sources for the Electricity Generation} in Turkey"

Table A1. Please rate the opinion on a five-point Likert scale on the following criteria in terms of their importance in analyzing RE sources.

\begin{tabular}{|c|c|c|c|c|c|}
\hline \multirow{2}{*}{ Criteria } & $\begin{array}{l}\text { Extremely } \\
\text { Important }\end{array}$ & $\begin{array}{c}\text { Very } \\
\text { Important }\end{array}$ & Neutral & $\begin{array}{c}\text { Low } \\
\text { Important }\end{array}$ & $\begin{array}{l}\text { Not at all } \\
\text { Important }\end{array}$ \\
\hline & 5 & 4 & 3 & 2 & 1 \\
\hline $\begin{array}{c}\text { Environmental criteria (ENF) } \\
\text { GHGs emissions (ENF1) } \\
\text { Land Requirement (ENF2) } \\
\text { Noise (ENF3) }\end{array}$ & & & & & \\
\hline $\begin{array}{c}\text { Economic criteria (ECF) } \\
\text { R\&D cost (ECF1) } \\
\text { Capital cost (ECF2) } \\
\text { Power generation cost (ECF3) } \\
\text { Resource Potential (ECF4) }\end{array}$ & & & & & \\
\hline $\begin{array}{c}\text { Technical criteria (TEF) } \\
\text { Technology maturity (TEF1) } \\
\text { On-grid access (TEF2) } \\
\text { HR experts (TEF3) } \\
\text { Efficiency (TEF4) }\end{array}$ & & & & & \\
\hline $\begin{array}{c}\text { Political criteria (POF) } \\
\text { RE policies and plans (POF1) } \\
\text { Institutional arrangements (POF2) } \\
\text { Energy Security (POF3) }\end{array}$ & & & & & \\
\hline $\begin{array}{c}\text { Social criteria (SOF) } \\
\text { Public acceptance (SOF1) } \\
\text { Employment opportunities (SOF2) } \\
\text { Public awareness (SOF3) }\end{array}$ & & & & & \\
\hline
\end{tabular}


Table A2. Demographic information of the experts.

\begin{tabular}{|c|c|c|c|c|c|}
\hline Serial Number & Designation & Gender & Qualification & Age & Organization \\
\hline 1 & Professor & Male & Ph.D. & 55 & Gazi University \\
\hline 2 & $\begin{array}{l}\text { Associate } \\
\text { Professor }\end{array}$ & Female & Ph.D. & 39 & Istanbul Technical University \\
\hline 3 & Professor & Male & Ph.D. & 53 & Ankara University \\
\hline 4 & Economist & Male & Ph.D. & 50 & Department of Trade \\
\hline 5 & $\begin{array}{c}\text { Economic } \\
\text { Analyst }\end{array}$ & Female & Masters & 42 & Economic Development Department \\
\hline 6 & Senior Manager & Male & Ph.D. & 45 & Alarko Energy Group \\
\hline 7 & $\begin{array}{l}\text { Project } \\
\text { Manager }\end{array}$ & Male & Ph.D. & 40 & Ankara Turkish Electric Power \\
\hline 8 & $\begin{array}{l}\text { Deputy } \\
\text { Secretary }\end{array}$ & Female & Masters & 42 & Ministry of Foreign Affairs \\
\hline 9 & Manager & Male & Masters & 45 & Turkish Electricity Transmission Corporation \\
\hline 10 & Director & Male & Ph.D. & 46 & Turkish Electricity Transmission Corporation \\
\hline 11 & Stakeholder & Male & Masters & 54 & Onur Energy, Izmir \\
\hline 12 & Stakeholder & Male & Masters & 50 & Park Green Energy, Ankara \\
\hline
\end{tabular}

\section{Appendix B. Fuzzy AHP Results}

Table A3. Fuzzy pairwise comparison with respect to the selection of RE sources.

\begin{tabular}{cccccc}
\hline & ENF & ECF & TEF & POF & SOF \\
\hline ENF & $(1.000,1.000,1.000)$ & $(0.250,0.490,1.000)$ & $(0.333,0.707,1.000)$ & $(0.250,0.357,1.000)$ & $(1.000,1.413,3.000)$ \\
ECF & $(1.000,2.041,4.000)$ & $(1.000,1.000,1.000)$ & $(0.333,1.259,3.000)$ & $(0.333,0.891,1.000)$ & $(1.000,2.450,4.000)$ \\
TEF & $(1.000,1.414,3.003)$ & $(0.333,0.794,3.003)$ & $(1.000,1.000,1.000)$ & $(0.333,0.500,1.000)$ & $(0.333,1.513,4.000)$ \\
POF & $(1.000,2.801,4.000)$ & $(1.000,1.122,3.003)$ & $(1.000,2.000,3.003)$ & $(1.000,1.000,1.000)$ & $(2.000,3.429,6.000)$ \\
SOF & $(0.333,0.708,1.000)$ & $(0.250,0.408,1.000)$ & $(0.250,0.661,3.003)$ & $(0.167,0.292,0.500)$ & $(1.000,1.000,1.000)$ \\
\hline
\end{tabular}

Table A4. Fuzzy pairwise comparison with respect to environmental criteria (ENF).

\begin{tabular}{cccc}
\hline & ENF1 & ENF2 & ENF3 \\
\hline ENF1 & $(1.000,1.000,1.000)$ & $(0.250,0.742,4.000)$ & $(0.250,1.259,4.000)$ \\
ENF2 & $(0.250,1.348,4.000)$ & $(1.000,1.000,1.000)$ & $(0.333,1.543,4.000)$ \\
ENF3 & $(0.250,0.794,4.000)$ & $(0.250,0.648,3.003)$ & $(1.000,1.000,1.000)$ \\
\hline
\end{tabular}

Table A5. Fuzzy pairwise comparison with respect to economic criteria (ECF).

\begin{tabular}{ccccc}
\hline & ECF1 & ECF2 & ECF3 & ECF4 \\
\hline ECF1 & $(1.000,1.000,1.000)$ & $(0.200,0.589,3.000)$ & $(0.250,0.891,4.000)$ & $(0.250,1.259,5.000)$ \\
ECF2 & $(0.333,1.698,5.000)$ & $(1.000,1.000,1.000)$ & $(1.000,1.413,3.000)$ & $(0.333,1.944,7.000)$ \\
ECF3 & $(0.250,1.122,4.000)$ & $(0.333,0.708,1.000)$ & $(1.000,1.000,1.000)$ & $(0.333,1.732,4.000)$ \\
ECF4 & $(0.200,0.794,4.000)$ & $(0.143,0.514,3.003)$ & $(0.250,0.577,3.003)$ & $(1.000,1.000,1.000)$ \\
\hline
\end{tabular}

Table A6. Fuzzy pairwise comparison with respect to technical criteria (TEF).

\begin{tabular}{ccccc}
\hline & TEF1 & TEF2 & TEF3 & TEF4 \\
\hline TEF1 & $(1.000,1.000,1.000)$ & $(1.000,2.000,5.000)$ & $(0.250,1.348,4.000)$ & $(0.250,1.586,4.000)$ \\
TEF2 & $(0.200,0.500,1.000)$ & $(1.000,1.000,1.000)$ & $(0.333,0.891,3.000)$ & $(0.250,0.779,4.000)$ \\
TEF3 & $(0.250,0.742,4.000)$ & $(0.333,1.122,3.003)$ & $(1.000,1.000,1.000)$ & $(0.250,0.874,5.000)$ \\
TEF4 & $(0.250,0.631,4.000)$ & $(0.250,1.284,4.000)$ & $(0.200,1.144,4.000)$ & $(1.000,1.000,1.000)$ \\
\hline
\end{tabular}


Table A7. Fuzzy pairwise comparison with respect to political criteria (POF).

\begin{tabular}{cccc}
\hline & POF1 & POF2 & POF3 \\
\hline POF1 & $(1.000,1.000,1.000)$ & $(0.333,1.347,4.000)$ & $(1.000,2.038,4.000)$ \\
POF2 & $(0.250,0.742,3.003)$ & $(1.000,1.000,1.000)$ & $(1.000,1.619,4.000)$ \\
POF3 & $(0.250,0.491,1.000)$ & $(0.250,0.618,1.000)$ & $(1.000,1.000,1.000)$ \\
\hline
\end{tabular}

Table A8. Fuzzy pairwise comparison with respect to social criteria (SOF).

\begin{tabular}{cccc}
\hline & SOF1 & SOF2 & SOF3 \\
\hline SOF1 & $(1.000,1.000,1.000)$ & $(0.333,1.070,4.000)$ & $(0.333,1.375,4.000)$ \\
SOF2 & $(0.250,0.935,3.003)$ & $(1.000,1.000,1.000)$ & $(1.000,1.348,4.000)$ \\
SOF3 & $(0.250,0.727,3.003)$ & $(0.250,0.742,1.000)$ & $(1.000,1.000,1.000)$ \\
\hline
\end{tabular}




\section{Appendix C. Fuzzy WASPAS Results}

Table A9. Fuzzy integrated decision matrix.

\begin{tabular}{|c|c|c|c|c|c|c|c|c|c|c|c|c|c|c|c|c|c|}
\hline & ENF1 & ENF2 & ENF3 & ECF1 & ECF2 & ECF3 & ECF4 & TEF1 & TEF2 & TEF3 & TEF4 & POF1 & POF2 & POF3 & SOF1 & SOF2 & SOF3 \\
\hline A1 & $\begin{array}{c}4.66 \\
6.66,8.33\end{array}$ & $\begin{array}{c}5.33 \\
7.16,8.5\end{array}$ & $\begin{array}{c}1.83 \\
3.33,5.16\end{array}$ & $\begin{array}{c}3.91 \\
5.83,7.58\end{array}$ & $\begin{array}{c}4.66 \\
6.33,7.75\end{array}$ & $\begin{array}{c}3,4.83 \\
6.66\end{array}$ & $\begin{array}{c}2.91 \\
4.66,6.50\end{array}$ & $\begin{array}{l}4.16 \\
6,7.83\end{array}$ & $\begin{array}{c}1.83 \\
3.33,5.16\end{array}$ & $\begin{array}{c}5.66 \\
7.50,8.91\end{array}$ & $4,6,7.83$ & $\begin{array}{c}2.75 \\
4.41,6.16\end{array}$ & $\begin{array}{c}3,4.83 \\
6.66\end{array}$ & $\begin{array}{c}4.16,6, \\
7.66\end{array}$ & $\begin{array}{c}4.66,6.33 \\
7.75\end{array}$ & $4,6,7.75$ & $\begin{array}{c}3.66 \\
5.50,7.25\end{array}$ \\
\hline A2 & $\begin{array}{c}5.08 \\
6.75,8\end{array}$ & $\begin{array}{l}4.58 \\
6.41,8\end{array}$ & $\begin{array}{c}5.83 \\
7.58,8.75\end{array}$ & $\begin{array}{c}2.25 \\
3.91,5.83\end{array}$ & $\begin{array}{c}5.83 \\
7.58,8.75\end{array}$ & $\begin{array}{r}1.58 \\
3,4.83\end{array}$ & $4,6,7.75$ & $\begin{array}{c}6.66 \\
8.33,9.33\end{array}$ & $\begin{array}{c}3.83 \\
5.66,7.41\end{array}$ & $\begin{array}{r}3.33 \\
5.16,7\end{array}$ & $\begin{array}{c}3.66 \\
5.41,7.08\end{array}$ & $\begin{array}{c}5.33 \\
7.16,8.58\end{array}$ & $\begin{array}{r}3.33 \\
5.16,7\end{array}$ & $\begin{array}{c}5.66 \\
7.50,8.91\end{array}$ & $\begin{array}{c}5.33 \\
7.16,8.58\end{array}$ & $3,5,7$ & $\begin{array}{c}4.66 \\
6.58,8.16\end{array}$ \\
\hline A3 & $\begin{array}{c}4.66, \\
6.50,8\end{array}$ & $\begin{array}{c}3.33 \\
5.08,6.83\end{array}$ & $\begin{array}{c}3.66 \\
5.41,7.08\end{array}$ & $\begin{array}{c}5,6.75 \\
8.08\end{array}$ & 2.2 & 4 & $\begin{array}{c}5.66 \\
7.33,8.50\end{array}$ & $\begin{array}{c}2.91 \\
4.66,6.50\end{array}$ & $\begin{array}{c}3.33, \\
5.08,6.83\end{array}$ & $\begin{array}{c}3.08 \\
4.83,6.66\end{array}$ & $\begin{array}{c}2.16, \\
3.66,5.50\end{array}$ & $\begin{array}{l}4,5.8 \\
7.58\end{array}$ & $\begin{array}{r}6.16 \\
7.83,9\end{array}$ & $\begin{array}{c}1.75 \\
3.50,5.50\end{array}$ & $\begin{array}{c}4.33 \\
6.25,7.83\end{array}$ & $\begin{array}{c}3.33 \\
5.08,6.83\end{array}$ & $\begin{array}{c}3.33 \\
5.08,6.83\end{array}$ \\
\hline A4 & $\begin{array}{r}2.58 \\
4.25,6\end{array}$ & $\begin{array}{c}2.41 \\
4.08,5.83\end{array}$ & $\begin{array}{r}4.33 \\
6,7.41\end{array}$ & $\begin{array}{c}1.25 \\
2.83,4.83\end{array}$ & $\begin{array}{c}2.50 \\
4.33,6.16\end{array}$ & $\begin{array}{c}4.16 \\
5.83,7.33\end{array}$ & $2.25,4,6$ & $\begin{array}{c}6.50 \\
8.25,9.41\end{array}$ & $\begin{array}{c}5,6.58 \\
7.83\end{array}$ & $\begin{array}{c}4.75 \\
6.41,7.83\end{array}$ & $\begin{array}{r}6.33 \\
8,9.08\end{array}$ & $\begin{array}{c}2.41 \\
4.08,5.83\end{array}$ & $\begin{array}{c}4.66 \\
6.41,7.75\end{array}$ & $\begin{array}{r}2.41, \\
4.16,6\end{array}$ & $\begin{array}{c}5,6.75 \\
8.08\end{array}$ & $\begin{array}{c}2.75 \\
4.41,6.16\end{array}$ & $\begin{array}{c}6.50 \\
8.16,9.25\end{array}$ \\
\hline A5 & $\begin{array}{c}3.75 \\
5.41,7.08\end{array}$ & $\begin{array}{c}4.16 \\
6.16,7.91\end{array}$ & $\begin{array}{r}3.50, \\
5.25,7\end{array}$ & $\begin{array}{c}4.83 \\
6.66,8.08\end{array}$ & $\begin{array}{r}1.58 \\
3,4.83\end{array}$ & $6,7.75,9$ & $\begin{array}{r}3.25 \\
5,6.75\end{array}$ & $2.25,4,6$ & $\begin{array}{c}1.83 \\
3.33,5.16\end{array}$ & $\begin{array}{c}2.66 \\
4.16,5.83\end{array}$ & $\begin{array}{c}4.08 \\
5.83,7.41\end{array}$ & $\begin{array}{c}1.75 \\
3.08,4.75\end{array}$ & $\begin{array}{c}4.16 \\
6.16,7.91\end{array}$ & $\begin{array}{c}2.41 \\
4.16,6.16\end{array}$ & $\begin{array}{c}5.50 \\
7.25,8.50\end{array}$ & $\begin{array}{c}4.66 \\
6.66,8.33\end{array}$ & $\begin{array}{c}4.16 \\
6.16,7.91\end{array}$ \\
\hline
\end{tabular}

Table A10. Fuzzy normalized decision matrix.

\begin{tabular}{cccccccccccccccccc}
\hline & ENF1 & ENF2 & ENF3 & ECF1 & ECF2 & ECF3 & ECF4 & TEF1 & TEF2 & TEF3 & TEF4 & POF1 & POF2 & POF3 & SOF1 & SOF2 & SOF3 \\
\hline \multirow{2}{*}{ A1 } & 0.56, & 0.62, & 0.20, & 0.48, & 0.53, & 0.33, & 0.34, & 0.44, & 0.23, & 0.63, & 0.44, & 0.32, & 0.33, & 0.46, & 0.54, & 0.48, & 0.39, \\
& $0.80,1$ & $0.84,1$ & $0.38,0.59$ & $0.72,0.93$ & $0.72,0.88$ & $0.53,0.74$ & $0.54,0.76$ & $0.63,0.83$ & $0.42,0.65$ & $0.84,1$ & $0.66,0.86$ & $0.51,0.71$ & $0.53,0.74$ & $0.67,0.85$ & $0.73,0.90$ & $0.72,0.93$ & $0.59,0.78$ \\
\hline \multirow{2}{*}{ A2 } & 0.61, & 0.53, & 0.66, & 0.27, & 0.66, & 0.17, & 0.47, & 0.70, & 0.48, & 0.37, & 0.40, & 0.62, & 0.37, & 0.63, & 0.62, & 0.36, & 0.50, \\
& $0.81,0.97$ & $0.75,0.94$ & $0.86,1$ & $0.48,0.72$ & $0.86,1$ & $0.33,0.53$ & $0.70,0.91$ & $0.88,0.99$ & $0.72,0.94$ & $0.57,0.78$ & $0.59,0.77$ & $0.83,1$ & $0.57,0.77$ & $0.84,1$ & $0.83,1$ & $0.60,0.84$ & $0.71,0.88$ \\
\hline \multirow{2}{*}{ A3 } & 0.56, & 0.39, & 0.41, & 0.61, & 0.25, & 0.44, & 0.66, & 0.30, & 0.42, & 0.34, & 0.23, & 0.46, & 0.68, & 0.19, & 0.50, & 0.40, & 0.36, \\
& $0.78,0.96$ & $0.59,0.80$ & $0.61,0.80$ & $0.83,1$ & $0.45,0.68$ & $0.66,0.86$ & $0.86,1$ & $0.49,0.69$ & $0.64,0.87$ & $0.54,0.74$ & $0.40,0.60$ & $0.67,0.88$ & $0.87,1$ & $0.39,0.61$ & $0.72,0.91$ & $0.61,0.82$ & $0.54,0.73$ \\
\hline \multirow{2}{*}{ A4 } & 0.31, & 0.28, & 0.49, & 0.15, & 0.28, & 0.46, & 0.26, & 0.69, & 0.63, & 0.53, & 0.69, & 0.28, & 0.51, & 0.27, & 0.58, & 0.33, & 0.70, \\
& $0.51,0.72$ & $0.48,0.68$ & $0.68,0.84$ & $0.35,0.59$ & $0.49,0.70$ & $0.64,0.81$ & $0.47,0.70$ & $0.87,1$ & $0.84,1$ & $0.71,0.87$ & $0.88,1$ & $0.47,0.67$ & $0.71,0.86$ & $0.46,0.67$ & $0.78,0.94$ & $0.53,0.74$ & $0.88,1$ \\
\hline \multirow{2}{*}{ A5 } & 0.45, & 0.49, & 0.40, & 0.59, & 0.18, & 0.66, & 0.38, & 0.23, & 0.23, & 0.29, & 0.44, & 0.20, & 0.46, & 0.27, & 0.64, & 0.56, & 0.45, \\
& $0.65,0.85$ & $0.72,0.93$ & $0.60,0.80$ & $0.82,1$ & $0.34,0.55$ & $0.86,1$ & $0.58,0.79$ & $0.42,0.63$ & $0.42,0.65$ & $0.46,0.65$ & $0.64,0.81$ & $0.35,0.55$ & $0.68,0.87$ & $0.46,0.69$ & $0.84,0.99$ & $0.80,1$ & $0.66,0.85$ \\
\hline
\end{tabular}


Table A11. Fuzzy weighted normalized matrix for WSM.

\begin{tabular}{|c|c|c|c|c|c|c|c|c|c|c|c|c|c|c|c|c|c|}
\hline & ENF1 & ENF2 & ENF3 & ECF1 & ECF2 & ECF3 & ECF4 & TEF1 & TEF2 & TEF3 & TEF4 & POF1 & POF2 & POF3 & SOF1 & SOF2 & SOF3 \\
\hline A1 & $\begin{array}{c}0.032, \\
0.046,0.058\end{array}$ & $\begin{array}{c}0.036 \\
0.048,0.058\end{array}$ & $\begin{array}{c}0.012 \\
0.022,0.034\end{array}$ & $\begin{array}{c}0.028 \\
0.041,0.054\end{array}$ & $\begin{array}{c}0.030 \\
0.042,0.051\end{array}$ & $\begin{array}{c}0.019 \\
0.031,0.043\end{array}$ & $\begin{array}{c}0.019 \\
0.031,0.044\end{array}$ & $\begin{array}{c}0.025 \\
0.037,0.048\end{array}$ & $\begin{array}{c}0.013 \\
0.024,0.038\end{array}$ & $\begin{array}{c}0.036 \\
0.048,0.058\end{array}$ & $\begin{array}{c}0.025 \\
0.038,0.050\end{array}$ & $\begin{array}{c}0.018 \\
0.029,0.041\end{array}$ & $\begin{array}{c}0.019 \\
0.031,0.043\end{array}$ & $\begin{array}{c}0.027 \\
0.039,0.049\end{array}$ & $\begin{array}{c}0.031 \\
0.042,0.052\end{array}$ & $\begin{array}{c}0.027 \\
0.041,0.053\end{array}$ & $\begin{array}{c}0.023 \\
0.034,0.045\end{array}$ \\
\hline A2 & $\begin{array}{c}0.035 \\
0.047,0.056\end{array}$ & $\begin{array}{c}0.031 \\
0.043,0.054 \\
\end{array}$ & $\begin{array}{c}0.038 \\
0.050,0.058\end{array}$ & $\begin{array}{c}0.016 \\
0.028,0.041\end{array}$ & $\begin{array}{c}0.038 \\
0.050,0.058\end{array}$ & $\begin{array}{c}0.010 \\
0.019,0.031\end{array}$ & $\begin{array}{c}0.027 \\
0.040,0.052\end{array}$ & $\begin{array}{c}0.041 \\
0.051,0.057\end{array}$ & $\begin{array}{c}0.028 \\
0.042,0.054\end{array}$ & $\begin{array}{c}0.021 \\
0.033,0.045\end{array}$ & $\begin{array}{c}0.023 \\
0.034,0.045\end{array}$ & $\begin{array}{c}0.036 \\
0.048,0.058\end{array}$ & $\begin{array}{c}0.021 \\
0.033,0.045\end{array}$ & $\begin{array}{c}0.036 \\
0.048,0.058\end{array}$ & $\begin{array}{c}0.036 \\
0.048,0.058 \\
\end{array}$ & $\begin{array}{c}0.020 \\
0.034,0.048\end{array}$ & $\begin{array}{c}0.029 \\
0.041,0.051\end{array}$ \\
\hline A3 & $\begin{array}{c}0.032 \\
0.045,0.055\end{array}$ & $\begin{array}{c}0.022 \\
0.034,0.046\end{array}$ & $\begin{array}{c}0.024 \\
0.035,0.047\end{array}$ & $\begin{array}{c}0.035 \\
0.048,0.058\end{array}$ & $\begin{array}{c}0.014 \\
0.026,0.039\end{array}$ & $\begin{array}{c}0.025 \\
0.038,0.049\end{array}$ & $\begin{array}{c}0.038 \\
0.050,0.058\end{array}$ & $\begin{array}{c}0.018 \\
0.028,0.040\end{array}$ & $\begin{array}{c}0.024 \\
0.037,0.050\end{array}$ & $\begin{array}{c}0.020 \\
0.031,0.043\end{array}$ & $\begin{array}{c}0.013 \\
0.023,0.035\end{array}$ & $\begin{array}{c}0.027 \\
0.039,0.051\end{array}$ & $\begin{array}{c}0.039 \\
0.050,0.058\end{array}$ & $\begin{array}{c}0.011 \\
0.022,0.035\end{array}$ & $\begin{array}{c}0.029 \\
0.042,0.052\end{array}$ & $\begin{array}{c}0.023 \\
0.035,0.047\end{array}$ & $\begin{array}{c}0.020 \\
0.031,0.042\end{array}$ \\
\hline A4 & $\begin{array}{c}0.018 \\
0.029,0.041\end{array}$ & $\begin{array}{c}0.016 \\
0.027,0.039\end{array}$ & $\begin{array}{c}0.028 \\
0.039,0.049\end{array}$ & $\begin{array}{c}0.009 \\
0.020,0.034\end{array}$ & $\begin{array}{c}0.016 \\
0.028,0.040\end{array}$ & $\begin{array}{c}0.026 \\
0.037,0.047\end{array}$ & $\begin{array}{c}0.015 \\
0.027,0.040\end{array}$ & $\begin{array}{c}0.040 \\
0.050,0.058\end{array}$ & $\begin{array}{c}0.037 \\
0.048,0.058\end{array}$ & $\begin{array}{c}0.030 \\
0.041,0.051\end{array}$ & $\begin{array}{c}0.040 \\
0.051,0.058\end{array}$ & $\begin{array}{c}0.016 \\
0.027,0.039\end{array}$ & $\begin{array}{c}0.030 \\
0.041,0.049\end{array}$ & $\begin{array}{c}0.015 \\
0.027,0.039\end{array}$ & $\begin{array}{c}0.033 \\
0.045,0.054\end{array}$ & $\begin{array}{c}0.019 \\
0.030,0.042\end{array}$ & $\begin{array}{c}0.040 \\
0.051,0.058\end{array}$ \\
\hline A5 & $\begin{array}{c}0.026 \\
0.037,0.049\end{array}$ & $\begin{array}{c}0.028 \\
0.042,0.054\end{array}$ & $\begin{array}{c}0.023 \\
0.034,0.046\end{array}$ & $\begin{array}{c}0.034 \\
0.047,0.058\end{array}$ & $\begin{array}{c}0.010 \\
0.019,0.032\end{array}$ & $\begin{array}{c}0.038 \\
0.049,0.058\end{array}$ & $\begin{array}{c}0.022 \\
0.034,0.046\end{array}$ & $\begin{array}{c}0.013 \\
0.024,0.037\end{array}$ & $\begin{array}{c}0.013 \\
0.024,0.038\end{array}$ & $\begin{array}{c}0.017 \\
0.027,0.037\end{array}$ & $\begin{array}{c}0.026 \\
0.037,0.047\end{array}$ & $\begin{array}{c}0.011 \\
0.020,0.032\end{array}$ & $\begin{array}{c}0.026 \\
0.039,0.051\end{array}$ & $\begin{array}{c}0.015 \\
0.027,0.040\end{array}$ & $\begin{array}{c}0.037 \\
0.049,0.057\end{array}$ & $\begin{array}{c}0.032, \\
0.046,0.058\end{array}$ & $\begin{array}{c}0.026 \\
0.038,0.049\end{array}$ \\
\hline
\end{tabular}

Table A12. Fuzzy weighted normalized matrix for WPM.

\begin{tabular}{|c|c|c|c|c|c|c|c|c|c|c|c|c|c|c|c|c|c|}
\hline & ENF1 & ENF2 & ENF3 & ECF1 & ECF2 & ECF3 & ECF4 & TEF1 & TEF2 & TEF3 & TEF4 & POF1 & POF2 & POF3 & SOF1 & SOF2 & SOF3 \\
\hline A1 & $\begin{array}{r}0.966, \\
0.987,1 \\
\end{array}$ & $\begin{array}{r}0.973, \\
0.990,1\end{array}$ & $\begin{array}{c}0.913 \\
0.945,0.969\end{array}$ & $\begin{array}{c}0.958, \\
0.981,0.996\end{array}$ & $\begin{array}{c}0.964, \\
0.981,0.993\end{array}$ & $\begin{array}{c}0.938, \\
0.964,0.982\end{array}$ & $\begin{array}{c}0.939 \\
0.965,0.984\end{array}$ & $\begin{array}{c}0.953 \\
0.974,0.989\end{array}$ & $\begin{array}{c}0.919 \\
0.951,0.976\end{array}$ & $\begin{array}{r}0.974, \\
0.990,1\end{array}$ & $\begin{array}{c}0.953 \\
0.976,0.991\end{array}$ & $\begin{array}{c}0.936 \\
0.962,0.981\end{array}$ & $\begin{array}{c}0.938, \\
0.964,0.982\end{array}$ & $\begin{array}{c}0.956 \\
0.977,0.991\end{array}$ & $\begin{array}{c}0.965 \\
0.982,0.994\end{array}$ & $\begin{array}{c}0.958 \\
0.981,0.995\end{array}$ & $\begin{array}{c}0.947 \\
0.970,0.986\end{array}$ \\
\hline A2 & $\begin{array}{c}0.971 \\
0.987,0.998\end{array}$ & $\begin{array}{c}0.964 \\
0.983,0.996\end{array}$ & $\begin{array}{r}0.976, \\
0.991,1 \\
\end{array}$ & $\begin{array}{c}0.928, \\
0.958,0.981\end{array}$ & $\begin{array}{r}0.976, \\
0.991,1 \\
\end{array}$ & $\begin{array}{c}0.904 \\
0.938,0.964\end{array}$ & $\begin{array}{c}0.957 \\
0.980,0.994\end{array}$ & $\begin{array}{c}0.980 \\
0.992,0.999\end{array}$ & $\begin{array}{c}0.959 \\
0.981,0.996\end{array}$ & $\begin{array}{c}0.944 \\
0.968,0.986\end{array}$ & $\begin{array}{c}0.948 \\
0.970,0.985\end{array}$ & $\begin{array}{c}0.972, \\
0.989,1 \\
\end{array}$ & $\begin{array}{c}0.944, \\
0.968,0.985\end{array}$ & $\begin{array}{r}0.974, \\
0.990,1\end{array}$ & $\begin{array}{r}0.972, \\
0.989,1\end{array}$ & $\begin{array}{c}0.942, \\
0.970,0.989\end{array}$ & $\begin{array}{c}0.961 \\
0.980,0.992\end{array}$ \\
\hline A3 & $\begin{array}{c}0.966, \\
0.985,0.997\end{array}$ & $\begin{array}{c}0.947 \\
0.970,0.987\end{array}$ & $\begin{array}{c}0.950 \\
0.972,0.987\end{array}$ & $\begin{array}{c}0.972, \\
0.989,1\end{array}$ & $\begin{array}{c}0.924 \\
0.955,0.978\end{array}$ & $\begin{array}{c}0.954 \\
0.976,0.991\end{array}$ & $\begin{array}{c}0.976, \\
0.991,1\end{array}$ & $\begin{array}{c}0.934 \\
0.960,0.978\end{array}$ & $\begin{array}{c}0.951, \\
0.975,0.992\end{array}$ & $\begin{array}{c}0.940 \\
0.965,0.983\end{array}$ & $\begin{array}{c}0.920 \\
0.948,0.971\end{array}$ & $\begin{array}{c}0.956 \\
0.977,0.992\end{array}$ & $\begin{array}{c}0.978, \\
0.992,1\end{array}$ & $\begin{array}{c}0.909 \\
0.947,0.972\end{array}$ & $\begin{array}{c}0.961 \\
0.981,0.994\end{array}$ & $\begin{array}{c}0.948 \\
0.971,0.988\end{array}$ & $\begin{array}{c}0.942, \\
0.965,0.982\end{array}$ \\
\hline A4 & $\begin{array}{c}0.934 \\
0.961,0.981\end{array}$ & $\begin{array}{c}0.929 \\
0.958,0.978\end{array}$ & $\begin{array}{c}0.960 \\
0.978,0.990\end{array}$ & $\begin{array}{c}0.897 \\
0.941,0.970\end{array}$ & $\begin{array}{c}0.929 \\
0.960,0.979\end{array}$ & $\begin{array}{c}0.956, \\
0.975,0.988\end{array}$ & $\begin{array}{c}0.925 \\
0.957,0.980\end{array}$ & $\begin{array}{c}0.978, \\
0.992,1\end{array}$ & $\begin{array}{c}0.974 \\
0.990,1\end{array}$ & $\begin{array}{c}0.964 \\
0.981,0.992\end{array}$ & $\begin{array}{c}0.979, \\
0.992,1\end{array}$ & $\begin{array}{c}0.929 \\
0.957,0.977\end{array}$ & $\begin{array}{c}0.962, \\
0.980,0.991\end{array}$ & $\begin{array}{c}0.927 \\
0.956,0.977\end{array}$ & $\begin{array}{c}0.969 \\
0.986,0.996\end{array}$ & $\begin{array}{c}0.937 \\
0.963,0.982\end{array}$ & $\begin{array}{c}0.979, \\
0.992,1\end{array}$ \\
\hline A5 & $\begin{array}{c}0.954 \\
0.975,0.990\end{array}$ & $\begin{array}{c}0.959 \\
0.981,0.995\end{array}$ & $\begin{array}{c}0.948 \\
0.970,0.987\end{array}$ & $\begin{array}{c}0.970, \\
0.988,1\end{array}$ & $\begin{array}{c}0.905 \\
0.939,0.966\end{array}$ & $\begin{array}{r}0.976, \\
0.991,1\end{array}$ & $\begin{array}{c}0.945 \\
0.969,0.986\end{array}$ & $\begin{array}{c}0.920 \\
0.951,0.974\end{array}$ & $\begin{array}{c}0.919 \\
0.951,0.976\end{array}$ & $\begin{array}{c}0.932 \\
0.956,0.975\end{array}$ & $\begin{array}{c}0.954 \\
0.974,0.988\end{array}$ & $\begin{array}{c}0.911 \\
0.942,0.966\end{array}$ & $\begin{array}{c}0.956 \\
0.978,0.992\end{array}$ & $\begin{array}{c}0.927 \\
0.956,0.978\end{array}$ & $\begin{array}{c}0.974 \\
0.990,0.999\end{array}$ & $\begin{array}{r}0.966, \\
0.987,1\end{array}$ & $\begin{array}{c}0.954 \\
0.976,0.991\end{array}$ \\
\hline
\end{tabular}




\section{References}

1. Wang, Y.; Xu, L.; Solangi, Y.A. Strategic Renewable Energy Resources Selection for Pakistan: Based on SWOT-Fuzzy AHP Approach. Sustain. Cities Soc. 2020, 52. [CrossRef]

2. Mastrocinque, E.; Ramírez, F.J.; Honrubia-Escribano, A.; Pham, D.T. An AHP-Based Multi-Criteria Model for Sustainable Supply Chain Development in the Renewable Energy Sector. Expert Syst. Appl. 2020, 150, 113321. [CrossRef]

3. The European Commission. The 2020 Climate and Energy Package; The European Commission: Brussels, Belgium, 2014.

4. Baležentis, T.; Streimikiene, D. Multi-Criteria Ranking of Energy Generation Scenarios with Monte Carlo Simulation. Appl. Energy 2017, 185, 862-871. [CrossRef]

5. Kotciolu, I. Clean and Sustainable Energy Policies in Turkey. Renew. Sustain. Energy Rev. 2011, 15, 5111-5119. [CrossRef]

6. Atilgan, B.; Azapagic, A. Renewable Electricity in Turkey: Life Cycle Environmental Impacts. Renew. Energy 2016, 89, 649-657. [CrossRef]

7. Simsek, H.A.; Simsek, N. Recent Incentives for Renewable Energy in Turkey. Energy Policy 2013, 63, 521-530. [CrossRef]

8. Solangi, Y.A.; Tan, Q.; Mirjat, N.H.; Ali, S. Evaluating the Strategies for Sustainable Energy Planning in Pakistan: An Integrated SWOT-AHP and Fuzzy-TOPSIS Approach. J. Clean. Prod. 2019, 236, 117655. [CrossRef]

9. Wu, Y.; Xu, C.; Zhang, T. Evaluation of Renewable Power Sources Using a Fuzzy MCDM Based on Cumulative Prospect Theory: A Case in China. Energy 2018, 147, 1227-1239. [CrossRef]

10. Kassem, A.; Al-Haddad, K.; Komljenovic, D.; Schiffauerova, A. A Value Tree for Identification of Evaluation Criteria for Solar Thermal Power Technologies in Developing Countries. Sustain. Energy Technol. Assess. 2016, 16, 18-32. [CrossRef]

11. Shen, Y.C.; Chou, C.J.; Lin, G.T.R. The Portfolio of Renewable Energy Sources for Achieving the Three E Policy Goals. Energy 2011, 36, 2589-2598. [CrossRef]

12. Ahmad, S.; Nadeem, A.; Akhanova, G.; Houghton, T.; Muhammad-Sukki, F. Multi-Criteria Evaluation of Renewable and Nuclear Resources for Electricity Generation in Kazakhstan. Energy 2017, 141, 1880-1891. [CrossRef]

13. Haddad, B.; Liazid, A.; Ferreira, P. A Multi-Criteria Approach to Rank Renewables for the Algerian Electricity System. Renew. Energy 2017, 107, 462-472. [CrossRef]

14. Ahmad, S.; Tahar, R.M. Selection of Renewable Energy Sources for Sustainable Development of Electricity Generation System Using Analytic Hierarchy Process: A Case of Malaysia. Renew. Energy 2014, 63, 458-466. [CrossRef]

15. Luthra, S.; Mangla, S.K.; Kharb, R.K. Sustainable Assessment in Energy Planning and Management in Indian Perspective. Renew. Sustain. Energy Rev. 2015, 47, 58-73. [CrossRef]

16. Tasri, A.; Susilawati, A. Selection among Renewable Energy Alternatives Based on a Fuzzy Analytic Hierarchy Process in Indonesia. Sustain. Energy Technol. Assess. 2014, 7, 34-44. [CrossRef]

17. Karatas, M.; Sulukan, E.; Karacan, I. Assessment of Turkey's Energy Management Performance via a Hybrid Multi-Criteria Decision-Making Methodology. Energy 2018, 153, 890-912. [CrossRef]

18. Papapostolou, A.; Karakosta, C.; Doukas, H. Analysis of Policy Scenarios for Achieving Renewable Energy Sources Targets: A Fuzzy TOPSIS Approach. Energy Environ. 2017, 28, 88-109. [CrossRef]

19. Ligus, M.; Peternek, P. Determination of Most Suitable Low-Emission Energy Technologies Development in Poland Using Integrated Fuzzy AHP-TOPSIS Method. Energy Procedia 2018, 153, 101-106. [CrossRef]

20. Solangi, Y.A.; Tan, Q.; Khan, M.W.A.; Mirjat, N.H.; Ahmed, I. The Selection of Wind Power Project Location in the Southeastern Corridor of Pakistan: A Factor Analysis, AHP, and Fuzzy-TOPSIS Application. Energies 2018, 11, 1940. [CrossRef]

21. Ren, J.; Sovacool, B.K. Prioritizing Low-Carbon Energy Sources to Enhance China's Energy Security. Energy Convers. Manag. 2015, 92, 129-136. [CrossRef]

22. Zhang, C.; Wang, Q.; Zeng, S.; Baležentis, T.; Štreimikienė, D.; Ališauskaitė-Šeškienė, I.; Chen, X. Probabilistic Multi-Criteria Assessment of Renewable Micro-Generation Technologies in Households. J. Clean. Prod. 2019, 212, 582-592. [CrossRef] 
23. Solangi, Y.A.; Shah, S.A.A.; Zameer, H.; Ikram, M.; Saracoglu, B.O. Assessing the Solar PV Power Project Site Selection in Pakistan: Based on AHP-Fuzzy VIKOR Approach. Environ. Sci. Pollut. Res. 2019, 26, 30286-30302. [CrossRef] [PubMed]

24. Troldborg, M.; Heslop, S.; Hough, R.L. Assessing the Sustainability of Renewable Energy Technologies Using Multi-Criteria Analysis: Suitability of Approach for National-Scale Assessments and Associated Uncertainties. Renew. Sustain. Energy Rev. 2014, 39, 1173-1184. [CrossRef]

25. Shakouri, G.H.; Aliakbarisani, S. At What Valuation of Sustainability Can We Abandon Fossil Fuels? A Comprehensive Multistage Decision Support Model for Electricity Planning. Energy 2016, 107, 60-77. [CrossRef]

26. Shmelev, S.E.; Van Den Bergh, J.C.J.M. Optimal Diversity of Renewable Energy Alternatives under Multiple Criteria: An Application to the UK. Renew. Sustain. Energy Rev. 2016, 60, 679-691. [CrossRef]

27. Santos, M.J.; Ferreira, P.; Araújo, M.; Portugal-Pereira, J.; Lucena, A.F.P.; Schaeffer, R. Scenarios for the Future Brazilian Power Sector Based on a Multi-Criteria Assessment. J. Clean. Prod. 2018, 167, 938-950. [CrossRef]

28. Çolak, M.; Kaya, İ. Prioritization of Renewable Energy Alternatives by Using an Integrated Fuzzy MCDM Model: A Real Case Application for Turkey. Renew. Sustain. Energy Rev. 2017, 80, 840-853. [CrossRef]

29. Şengül, Ü.; Eren, M.; Eslamian Shiraz, S.; Gezder, V.; Sengül, A.B. Fuzzy TOPSIS Method for Ranking Renewable Energy Supply Systems in Turkey. Renew. Energy 2015, 75, 617-625. [CrossRef]

30. Wang, J.J.; Jing, Y.Y.; Zhang, C.F.; Zhao, J.H. Review on Multi-Criteria Decision Analysis Aid in Sustainable Energy Decision-Making. Renew. Sustain. Energy Rev. 2009, 13, 2263-2278. [CrossRef]

31. Brand, B.; Missaoui, R. Multi-Criteria Analysis of Electricity Generation Mix Scenarios in Tunisia. Renew. Sustain. Energy Rev. 2014, 39, 251-261. [CrossRef]

32. Kang, D.; Lee, D.H. Energy and Environment Efficiency of Industry and Its Productivity Effect. J. Clean. Prod. 2016, 135, 184-193. [CrossRef]

33. Shen, Y.C.; Lin, G.T.R.; Li, K.P.; Yuan, B.J.C. An Assessment of Exploiting Renewable Energy Sources with Concerns of Policy and Technology. Energy Policy 2010, 38, 4604-4616. [CrossRef]

34. Shah, S.A.A.; Solangi, Y.A. A Sustainable Solution for Electricity Crisis in Pakistan: Opportunities, Barriers, and Policy Implications for 100\% Renewable Energy. Environ. Sci. Pollut. Res. 2019, 26, 29687-29703. [CrossRef]

35. Wang, C.N.; Huang, Y.F.; Chai, Y.C.; Nguyen, V.T. A Multi-Criteria Decision Making (MCDM) for Renewable Energy Plants Location Selection in Vietnam under a Fuzzy Environment. Appl. Sci. 2018, 8, 2069. [CrossRef]

36. Marinakis, V.; Doukas, H.; Xidonas, P.; Zopounidis, C. Multicriteria Decision Support in Local Energy Planning: An Evaluation of Alternative Scenarios for the Sustainable Energy Action Plan. Omega 2017, 69, 1-16. [CrossRef]

37. Kahraman, C.; Kaya, I.; Cebi, S. A Comparative Analysis for Multiattribute Selection among Renewable Energy Alternatives Using Fuzzy Axiomatic Design and Fuzzy Analytic Hierarchy Process. Energy 2009, 34, 1603-1616. [CrossRef]

38. Amer, M.; Daim, T.U. Selection of Renewable Energy Technologies for a Developing County: A Case of Pakistan. Energy Sustain. Dev. 2011, 15, 420-435. [CrossRef]

39. Shah, S.A.A.; Solangi, Y.A.; Ikram, M. Analysis of Barriers to the Adoption of Cleaner Energy Technologies in Pakistan Using Modified Delphi and Fuzzy Analytical Hierarchy Process. J. Clean. Prod. 2019, 235, 1037-1050. [CrossRef]

40. Zhao, X.; Feng, T.; Lu, C.; Feng, X. The Barriers and Institutional Arrangements of the Implementation of Renewable Portfolio Standard: A Perspective of China. Renew. Sustain. Energy Rev. 2014, 30, 371-380.

41. Shah, A.A.; Qureshi, S.M.; Bhutto, A.; Shah, A. Sustainable Development through Renewable Energy-The Fundamental Policy Dilemmas of Pakistan. Renew. Sustain. Energy Rev. 2011, 15, 861-865. [CrossRef]

42. Sahir, M.H.; Qureshi, A.H. Specific Concerns of Pakistan in the Context of Energy Security Issues and Geopolitics of the Region. Energy Policy 2007, 35, 2031-2037. [CrossRef]

43. Rani, P.; Mishra, A.R.; Mardani, A.; Cavallaro, F.; Alrasheedi, M.; Alrashidi, A. A Novel Approach to Extended Fuzzy TOPSIS Based on New Divergence Measures for Renewable Energy Sources Selection. J. Clean. Prod. 2020, 257, 120352. [CrossRef]

44. Solangi, Y.A.; Tan, Q.; Mirjat, N.H.; Valasai, G.D.; Khan, M.W.A.; Ikram, M. An Integrated Delphi-AHP and Fuzzy TOPSIS Approach toward Ranking and Selection of Renewable Energy Resources in Pakistan. Processes 2019, 7, 118. [CrossRef] 
45. Kabak, M.; Dağdeviren, M. Prioritization of Renewable Energy Sources for Turkey by Using a Hybrid MCDM Methodology. Energy Convers. Manag. 2014, 79, 25-33. [CrossRef]

46. Deveci, K.; Güler, Ö. A CMOPSO Based Multi-Objective Optimization of Renewable Energy Planning: Case of Turkey. Renew. Energy 2020, 155, 578-590. [CrossRef]

47. Dinçer, F. Overview of the Photovoltaic Technology Status and Perspective in Turkey. Renew. Sustain. Energy Rev. 2011, 15, 3768-3779. [CrossRef]

48. Anser, M.K.; Mohsin, M.; Abbas, Q.; Chaudhry, I.S. Assessing the Integration of Solar Power Projects: SWOT-Based AHP-F-TOPSIS Case Study of Turkey. Environ. Sci. Pollut. Res. 2020. [CrossRef]

49. SOLARGIS. Solar Resource Maps and GIS Data for 180+ Countries|Solargis. Available online: https: //solargis.com/maps-and-gis-data/download (accessed on 9 September 2019).

50. IEA. Energy Policies of IEA Countries-Turkey. 2009. Available online: https://webstore.iea.org/energypolicies-of-iea-countries-turkey-2009-review (accessed on 11 July 2020).

51. Ilkiliç, C.; Aydin, H.; Behçet, R. The Current Status of Wind Energy in Turkey and in the World. Energy Policy 2011, 39, 961-967. [CrossRef]

52. Melikoglu, M. Vision 2023: Feasibility Analysis of Turkey's Renewable Energy Projection. Renew. Energy 2013, 50, 570-575. [CrossRef]

53. International Hydropower Association. Hydropower Status Report; International Hydropower Association: London, UK, 2018. Available online: https:/www.hydropower.org/publications/2018-hydropower-statusreport (accessed on 11 July 2020).

54. Akpinar, A.; Kömürcü, M.I.; Önsoy, H.; Kaygusuz, K. Status of Geothermal Energy amongst Turkey's Energy Sources. Renew. Sustain. Energy Rev. 2008, 12, 1148-1161. [CrossRef]

55. Amponsah, N.Y.; Troldborg, M.; Kington, B.; Aalders, I.; Hough, R.L. Greenhouse Gas Emissions from Renewable Energy Sources: A Review of Lifecycle Considerations. Renew. Sustain. Energy Rev. 2014, 39, 461-475. [CrossRef]

56. Toklu, E. Biomass Energy Potential and Utilization in Turkey. Renew. Energy 2017, 107, 235-244. [CrossRef]

57. Mahajan, V.; Linstone, H.A.; Turoff, M. The Delphi Method: Techniques and Applications. J. Mark. Res. 1976, 13, 317. [CrossRef]

58. Skulmoski, G.J.; Hartman, F.T. The Delphi Method for Graduate Research. J. Inf. Technol. Educ. 2007, 6, 1-21. [CrossRef]

59. Gordon, T.; Pease, A. RT Delphi: An Efficient, “Round-Less” Almost Real Time Delphi Method. Technol. Forecast. Soc. Chang. 2006, 73, 321-333. [CrossRef]

60. Phonphoton, N.; Pharino, C. Multi-Criteria Decision Analysis to Mitigate the Impact of Municipal Solid Waste Management Services during Floods. Resour. Conserv. Recycl. 2019, 146, 106-113. [CrossRef]

61. Kaganski, S.; Majak, J.; Karjust, K. Fuzzy AHP as a Tool for Prioritization of Key Performance Indicators. Procedia CIRP 2018, 72, 1227-1232. [CrossRef]

62. Gogus, O.; Boucher, T.O. Strong Transitivity, Rationality and Weak Monotonicity in Fuzzy Pairwise Comparisons. Fuzzy Sets Syst. 1998, 94, 133-144. [CrossRef]

63. Turskis, Z.; Goranin, N.; Nurusheva, A.; Boranbayev, S. A Fuzzy WASPAS-Based Approach to Determine Critical Information Infrastructures of EU Sustainable Development. Sustainability 2019, 11, 424. [CrossRef]

64. Chakraborty, S.; Zavadskas, E.K.; Antucheviciene, J. Applications of WASPAS Method as a Multi-Criteria Decision-Making Tool. Econ. Comput. Econ. Cybern. Stud. Res. 2015, 49, 5-22.

65. Turskis, Z.; Zavadskas, E.K.; Antucheviciene, J.; Kosareva, N. A Hybrid Model Based on Fuzzy AHP and Fuzzy WASPAS for Construction Site Selection. Int. J. Comput. Commun. Control 2015, 10, 873-888. [CrossRef]

(C) 2020 by the authors. Licensee MDPI, Basel, Switzerland. This article is an open access article distributed under the terms and conditions of the Creative Commons Attribution (CC BY) license (http://creativecommons.org/licenses/by/4.0/). 